\title{
PALHETAS DE OBOÉ: CONFECÇÃO, MATERIAIS E FERRAMENTAS
}

\section{OBOE REEDS: MAKING, MATERIALS AND TOOLS}

\author{
Josiane Cristina Cicolani \\ Universidade de São Paulo \\ josiane.marques@yahoo.com.br \\ Simone Corete Machado \\ Universidade de São Paulo \\ simonegorete@usp.br
}

\section{Resumo}

presente trabalho tem como objetivo organizar informações sobre a confecção de palhetas e o manuseio das ferramentas necessárias para esse fim. Será abordado um breve histórico do instrumento e seus antecessores, expondo a evolução dos primeiros oboés até os modelos atuais. Também serão abordados temas como a origem das canas, região em que estas são cultivadas, e os procedimentos desenvolvidos, desde a cana in natura até o processo final da raspagem. Outros tópicos do trabalho incluirão: moldagem e amarração das canas, tipos de raspagens com abordagem detalhada na raspagem alemã e as ferramentas necessárias para todos os procedimentos pelos quais se chega ao final do processo em que a palheta esteja funcionando com equilibrio, ressonância e flexibilidade.

Palavras-chave: oboé; palheta; raspagem.

\section{Abstract}

This work's goal is to guide the beginner in oboe's playing on the preparation of their own reed along with suggestions on how to handle the utensils necessary for this task. We present here a short history of

I ClCOLANI, J.C. Palhetas de oboé. 2015. 65f. Trabalho de Conclusão de Curso Departamento de Música da Faculdade de Filosofia, Ciências e Letras de Ribeirão Preto da Universidade de São Paulo, Ribeirão Preto, 2015. 
the instrument and its predecessors showing the evolution from the first oboes to the contemporary models. There will also be presented topics such as the cane's origin, its source, region and procedures on how to go from the cane in natura until the last part of the scraping. In addition, we detailed the canes' molding and mooring procedure along with its scraping, specially the german kind. We hope to contribute to the craft that leads towards a balanced, flexible and vibrant sounding reed.

Keywords: oboe; reed; scraping.

\section{Lista de figuras}

Figura 1: Zurna (Fonte: Neuhaus et al., 1998).

Figura 2: Charamela (Fonte: Burgess; Haynes, 2004).

Figura 3: Palhetas (Fonte: Burgess; Haynes, 2004).

Figura 4: Cana em tubos (Fonte: Neuhaus et al., 1998).

Figura 5: Pré-goiva (Fonte: http://images.google.com/).

Figura 6: Goiva (Fonte: http://images.google.com/).

Figura 7: Canas goivadas (Fonte: acervo da autora).

Figura 8: Micrômetro (Fonte: acervo da autora).

Figura 9: Molde Chiarugi nº2 (Fonte: acervo da autora).

Figura 10: (A) Cabo do molde; (B) Cabo com o molde (Fonte: acervo da autora).

Figura 1 1: Modelos de Mandril (Fonte: acervo da autora).

Figura 12: Linha de Nylon (Fonte: acervo da autora).

Figura 13: Lingueta de madeira, plástico e metal (Fonte: acervo da autora).

Figura 14: Tubo (Fonte: acervo da autora). 
Figura 15: Pedra para afiar (Fonte: acervo da autora).

Figura 16: Assentador de fios (Fonte: acervo da autora).

Figura 17: Paquímetro (Fonte: acervo da autora).

Figura 18: (A) Rolo de arame; (B) Arame abrindo a palheta (Fonte: acervo da autora).

Figura 19: Alicate de bico (Fonte: acervo da autora).

Figura 20: (A) Bloco de corte; (B) Guilhotina (Fonte: acervo da autora).

Figura 21: Guia ou marcador (Fonte: acervo da autora).

Figura 22: Facas de chanfro duplo e simples (Fonte: acervo da autora).

Figura 23: Borracha de látex (Fonte: acervo da autora).

Figura 24: Lixa d'água (Fonte: acervo da autora).

Figura 25: Cana goivada e moldada (Fonte: acervo da autora).

Figura 26: Tabela de medidas para moldes. (Fonte: Ledet, 2008).

Figura 27: (A) Cana recém-molhada para ser moldada; (B) Cana pronta para ser moldada (Fonte: acervo da autora).

Figura 28: Cana dobrada ao meio (Fonte: Neuhaus et al., 1998).

Figura 29: Corte das laterais da cana (Fonte: Neuhaus et al., 1998).

Figura 30: Cana no molde. (Fonte: Making Oboe Reeds, Shalita, 2003).

Figura 31: Cana com borracha de látex (Fonte: acervo da autora).

Figura 32: Cana com overlap (Fonte: acervo da autora).

Figura 33: Cana no paquímetro medindo 75 mm (Fonte: acervo da autora).

Figura 34: (A) Marcação do final do tubo; (B) Cana marcada no mandril (Fonte: acervo da autora). 
Figura 35: Mão segurando o carretel e a linha (Fonte: Neuhaus et al., 1998).

Figura 36: Amarrando a cana (Fonte: acervo da autora).

Figura 37: Virada da linha (Fonte: acervo da autora).

Figura 38: Fazendo o nó na palheta (Fonte: acervo da autora).

Figura 39: (A) Cana com dois nós; (B) Cortando a linha com estilete (Fonte: acervo da autora).

Figura 40: Cana amarrada (Fonte: acervo da autora).

Figura 4 1: Partes da cana. (Fonte: Neuhaus et al., 1998).

Figura 42: Molhando a ponta da palheta (Fonte: acervo da autora).

Figura 43: Marcação e raspagem da ponta (Fonte: acervo da autora).

Figura 44: (A) Cortando a ponta; (B) Ponta aberta (Fonte: acervo da autora).

Figura 45: (A) Raspando a ponta com a lixa; (B) Ponta já raspada (Fonte: acervo da autora).

Figura 46: Marcação do início da raspagem (Fonte: acervo da autora).

Figura 47: (A) Marcação da coluna; (B) Marcação do lado direito (LD) e do lado esquerdo (LE) (Fonte: acervo da autora).

Figura 48: Marcação da raspagem da ponta (Fonte: acervo da autora).

Figura 49: Raspando a ponta da palheta (Fonte: acervo da autora).

Figura 50: Medindo a ponta da palheta com micrômetro (Fonte: acervo da autora).

Figura 51 : "Degrau" na ponta da palheta (Fonte: acervo da autora).

Figura 52: Marcação do "W" (Fonte: acervo da autora). 


\section{Introdução}

$\bigcirc$ que fazer quando, no início do aprendizado de oboé, a palheta se torna um grande empecilho para o desenvolvimento técnico e musical? Quando e como devo adquirir o material necessário para confeccionar a palheta? Essas são dúvidas comuns entre os iniciantes de oboé, pois a palheta é um elemento primordial para que haja evolução na aprendizagem. Diferente de muitos instrumentos, em se tratando do oboé, não basta investir apenas na compra do instrumento musical, mas também na aquisição do material para a confecção das palhetas. Embora existam palhetas já disponíveis para o uso no mercado, nem sempre elas funcionam em determinadas regiões geográficas, pois são suscetíveis às variações climáticas, sendo necessário um ajuste por parte do instrumentista.

Para que o musicista faça sua própria palheta, quanto antes as ferramentas e os materiais forem adquiridos, melhor. Desse modo, a evolução no aprendizado musical poderá ser paralela ao aprendizado da confecção. Entretanto, é importante que se tenha orientação específica de um especialista, desde os primórdios do estudo, em ambos os assuntos. Além do mais, muitos alunos, por residirem longe dos grandes centros de ensino musical, encontram ainda dificuldades quanto ao acesso a professores e às informações corretas de como proceder nos estudos específicos desse instrumento. Este é um dos fatores que contribuem para que muitos alunos desistam da oportunidade de aprenderem a manejar esse instrumento. Estas são razões que justificam o presente estudo desenvolvido com o intuito de auxiliar os iniciantes no aprendizado do oboé proporcionando-lhes orientações para a confecção de palhetas.

\section{Histórico}

$\bigcirc$ princípio da utilização de palhetas duplas para a produção de som em instrumentos musicais é muito antigo. Pesquisas de Geoffrey Burguess e Bruce Haynes (2004), ambos oboístas e musicólogos, relatam no livro The Oboe que, por volta de 3000 a.C, surgiram instrumentos de palheta dupla na região da Mesopotâmia. Foram encontradas representações pictóricas de instrumentos desse tipo no Egito desde o 
ano 2000 a.C. Na Grécia, existia o aulos, que foi difundido posteriormente em Roma com o nome de Tíbia. Esses instrumentos perderam espaço para outros aerófonos, por volta do século $V$, com as invasões dos povos do norte e só reapareceram por volta do século VIII com a invasão da Península lbérica pelos árabes, que muito utilizavam a Zurna para eventos em ambientes externos (Burgess; Haynes, 2004, p.7-9).

Zurna é um instrumento que tem uma aproximação maior com - conhecido oboé por utilizar palheta dupla e ter o corpo cônico. Era construido em madeira de árvores frutíferas, possuía seis ou sete furos, campana aberta e variava em tamanho e afinação (Figura 1). A palheta da Zurna podia ser feita de junco, caule ou folha de milho, capim, folha de palma, palha ou outro material flexivel. A palheta era tão flexível que se os lábios a tocassem, inibiria a vibração da mesma. Então, se fez necessária a utilização de um disco de metal denominado pirovette, também chamado de virola, que servia para apoiar os lábios, deixando a palheta completamente dentro da boca (Burgess; Haynes, 2004, p. 15-21).

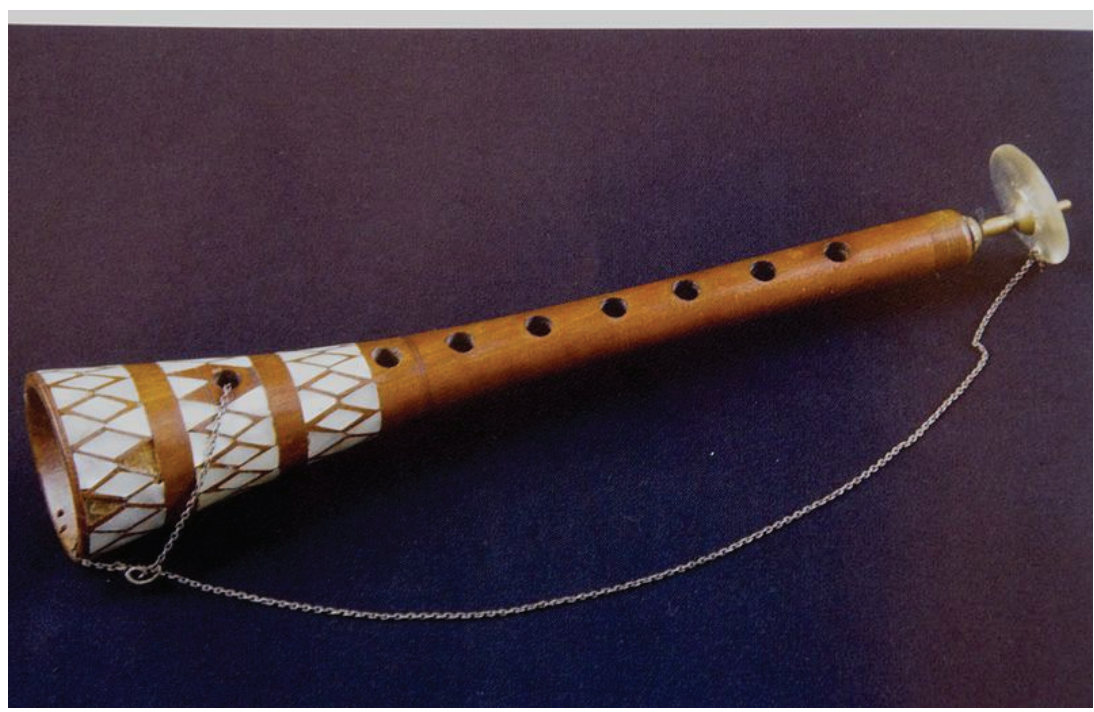

Figura 1: Zurna (Fonte: Neuhaus et al., 1998).

Durante os séculos XII e XIII, a Zurna passou por algumas modificações na Europa e deu origem à Charamela. $\bigcirc$ corpo do 
instrumento ainda era uma única peça, porém se tornou mais longo e a palheta um pouco mais longa e ligeiramente mais estreita. Ainda possuía o pirovette, mas esse se aproximou um pouco mais da palheta, permitindo que os lábios tocassem a base dela. Dessa forma havia controle parcial da palheta, que nesse momento passa a ser produzida com cana Arundo Donax. $O$ aumento do comprimento do instrumento e da palheta somados ao estreitamento da palheta e a utilização de uma cana específica, tornaram a Charamela um instrumento mais sonoro que a Zurna (Figura 2). Este instrumento reinou da metade do século XIII até meados do século XVII, quando acontece o surgimento (cerca de 1657) do oboé francês.

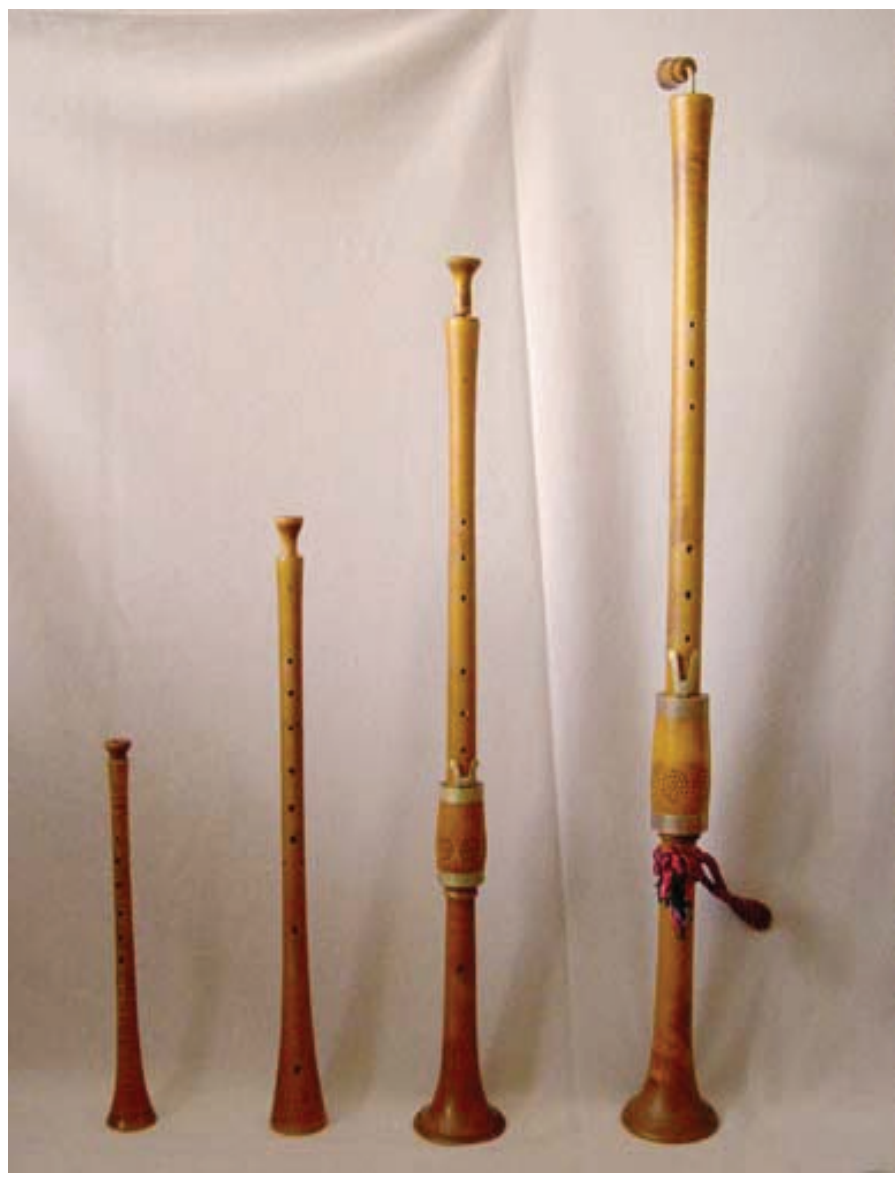

Figura 2: Charamela (Fonte: Burgess; Haynes, 2004). 
oboé francês, instrumento sucessor da Charamela, do qual evoluiu o atual oboé, surgiu por volta do ano de 1650 na corte de Louis XIV. Jean Hotteterre I, gaiteiro da corte e construtor de muitos instrumentos, juntamente com Michel Philidor, virtuoso de muitos instrumentos de sopro, inventaram o oboé francês. No período renascentista, ocorreram mudanças na música como a passagem da polifonia para a monodia, convencionando o baixo contínuo na harmonia. Também houve mudanças na formação performática. A charamela era utilizada em conjuntos de diferentes tamanhos, que costumavam se apresentar em ambientes externos. Nessa época a música não era escrita especificamente para charamelas. Já o oboé surgiu para ser tocado em ambientes internos, com a função de solista e colaborador orquestral, enfatizando a arte da retórica da música barroca. $\bigcirc$ novo oboé francês tinha seu corpo dividido em três partes e sua perfuração interna era ligeiramente mais estreita.

diâmetro dos furos no tubo do instrumento fora reduzido, com os quais produziram-se as diferentes notas no tubo cilíndrico do oboé, mas a principal mudança foi a retirada do pirovette, surgindo um novo estilo de palheta, que podia ser controlada pelos lábios. Pela primeira vez, um instrumento de palheta dupla tinha sua sonoridade controlada, mais refinada e adequada a ambientes internos. $\bigcirc$ som desse instrumento era próximo do oboé atual, mas possuía menos harmônicos agudos, devido a sua palheta ser mais larga. Sabe-se que as palhetas, nesse período, possuíam 9,5 mm de largura e $98 \mathrm{~mm}$ de comprimento (Burgess; Haynes, 2004, p. 98). A palheta utilizada na atualidade tem cerca de $7 \mathrm{~mm}$ de largura e $71 \mathrm{~mm}$ de comprimento. Este novo instrumento logo desfrutou de imediato sucesso internacional.

Durante o século XVIII, o instrumento ganhou de duas a três chaves (oboé barroco do início do século XVIII) e logo evoluiu para o oboé clássico ainda no final do século. Provavelmente, as mudanças mais importantes foram o estreitamento progressivo do corpo e a adição de seis a dez chaves. As palhetas usadas nesses instrumentos ainda eram mais largas do que as de hoje; mediam por volta de 8 a $10 \mathrm{~mm}$ (Ledet, 2008, p.36).

Os principais avanços do século XIX consistem em estreitamento e uma forma ligeiramente diferente do corpo do oboé: mudança da madeira (antes de árvores frutíferas para ébano ou granadilla), estabilização da afinação, adição de chaves, melhor localização dos 
furos e estreitamento das palhetas. Instruções detalhadas do processo de fabricação de palhetas começaram a aparecer no séc. XIX, mas a maioria das informações eram passadas oralmente, o que é mantido atualmente (Figura 3).
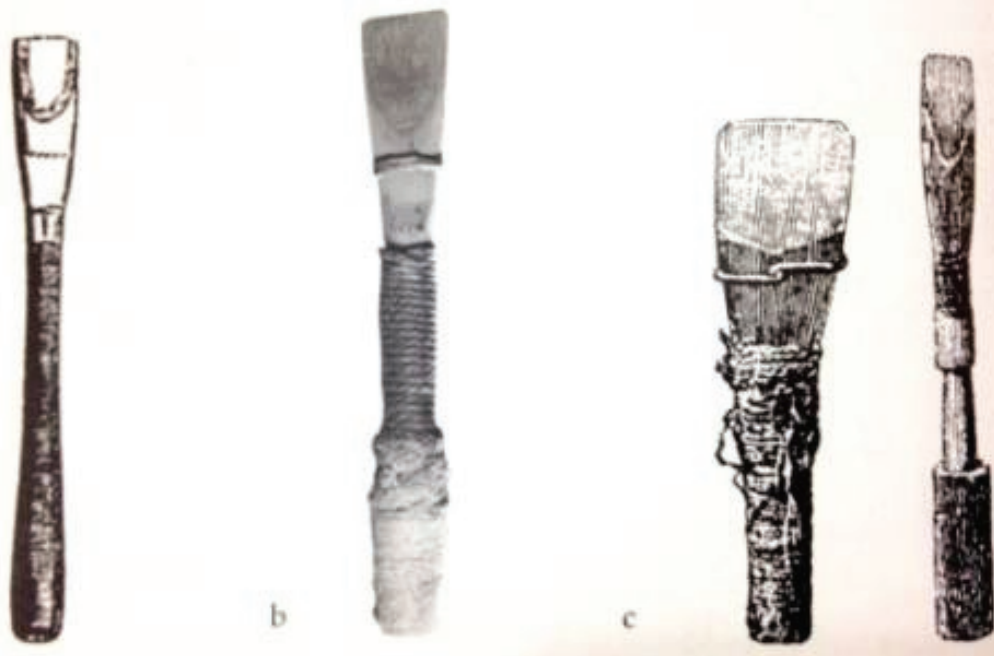

Figura 3: Palhetas (Fonte: Burgess; Haynes, 2004).

Em suma, o corpo do oboé se tornou mais estreito através dos séculos, mais chaves foram adicionadas para facilitar a técnica e a afinação, a madeira utilizada para a fabricação do corpo foi cada vez mais pesada para melhorar a ressonância e graças aos princípios de Boehm, Helmholtz, e avanços na ciência da acústica, os furos tonais evoluíram em espaçamento, tamanho e corte para melhorar na afinação e reação. Por fim, a palheta se tornou mais controlável pelos lábios à medida que se livrou do pirouette, estreitou-se e ficou menor. Todas essas transformações afetaram no timbre do instrumento $e$, consequentemente, no raspado da palheta. Por outro lado, a mecanização do oboé afetou o desenho da palheta. Com a introdução da chave de oitava, não eram mais necessárias palhetas tão longas para suportar a pressão do ar com maior frequência de notas acima do ré3. Também se fazia 
necessária a utilização de palhetas um pouco mais duras.

Com o crescimento da orquestra, que multiplicou de tamanho, o oboísta teve que enfrentar grandes salas de concerto e uma música muito mais densa, necessitando de uma palheta que tivesse maior ressonância sonora, de modo a sobressair em um contexto e não perder o refinamento em outro. Nos séculos seguintes, os oboístas fizeram muitos experimentos com palhetas e se tornaram mais minuciosos no assunto. No século XX ficaram definidas algumas escolas de estilo de palhetas, que buscavam, cada uma dentro de seu espaço, uma determinada sonoridade e estilo de interpretação. Segundo Ledet (2008), se destacaram por uma uniformização as escolas:

- FRANCESA: buscava proeza na técnica e comodidade para a execução de articulação leve. Oferecia pouca resistência na coluna de ar e na embocadura. Isso se conseguia raspando o primeiro terço da palheta, inclusive o coração. Possuía goivado fino ( $0,5 \mathrm{~mm}$ ), raspado curto ( $8 \mathrm{~mm}$, ou menos), ponta muito fina e comprida.

- ALEMÃ: buscava espectro sonoro nos primeiros harmônicos e enfraquecia os agudos para tirar a aspereza do timbre. Conseguia isso com um raspado curto, coração pronunciado e goivado mais fino. Esse sistema exigia uma embocadura mais ativa.

- AMERICANA: essa escola é, supostamente, uma derivação, agora já bem distante, da escola francesa. Seu criador foi Marcel Tabuteau, um francês que se radicou nos EUA, que juntamente com seus alunos conseguiu domínio quase total no país. Com a ponta e o raspado mais longo, os adeptos dessa escola buscam um timbre com espectro de harmônicos mais amplo e resistência menor à embocadura, para uma execução cômoda. A embocadura influencia pouco na sonoridade em comparação com outras escolas.

- HOLANDESA: goivado grosso (0,75-0,8mm), forma larga (7,5$8 \mathrm{~mm})$, tubo muito curto $(42 \mathrm{~mm})$ e raspado relativamente longo (dois terços da cana). Desenvolvida por Jaap Stotijn. Conseguiam menos esforço para o oboísta em relação à pressão labial buscando relaxamento e flexibilidade. A moldagem larga e o goivado grosso garantiam um som estável e com boa projeção (Ledet, 2008, p.88-101). 


\section{Ferramentas}

Uma das principais dúvidas dos estudantes de oboé quando se predispõem a confeccionar as próprias palhetas está relacionada à aquisição dos materiais necessários para que isso seja possivel. Nesta etapa do aprendizado o aluno se depara com o alto custo das ferramentas que, por serem muito específicas, são encontradas com restrições de acesso e variedades de revendedores, principalmente no Brasil. A maioria desses produtos são importados e isso gera um custo alto.

Existem no mercado alguns profissionais que disponibilizam a palheta pronta para a venda, mas nem sempre funcionam como o esperado, pois a variação climática e a combinação instrumentopalheta pode não ser a ideal para o equipamento ao qual esteja sendo usada. Por isso, a necessidade do oboísta de aprender a confeccionar as próprias palhetas. As ferramentas básicas que devem ser priorizadas nessa etapa do aprendizado são: canas, tubos, linha, mandril, lingueta, paquímetro ou uma régua, que serão apresentadas a seguir:

\subsection{Cana}

De nome científico Arundo Donax, da família Poaceae, a cana é uma espécie de planta com flor, nativa das águas frescas do Mediterrâneo, da qual são retirados os tubos, os quais passam pelos processos de pré-goivagem e goivagem que darão origem às lâminas da palheta. Diferentemente da popular cana-de-açúcar, a Arundo Donax, também chamada de cana-do-reino, é a única espécie adequada para a produção de palhetas, por ter boa flexibilidade e qualidade de ressonância.

Uma das recomendações constatada é a de que a seleção das canas deve ser feita entre as que possuem a casca lisa e brilhante, evitando-se os tubos de cor esverdeada, que estejam torcidos e ovalados. Normalmente, desses tubos originarão canas moles, que afetarão o som (Figura 4). 


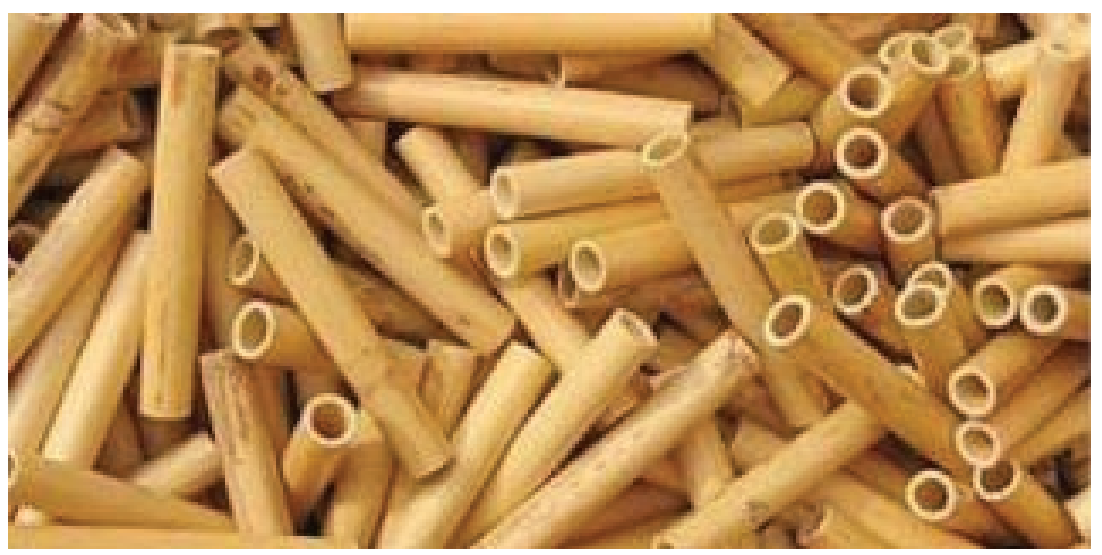

Figura 4: Cana em tubos (Fonte: Neuhaus et al., 1998).

A Figura 4 demonstrou os tubos com dois a três anos de cultivo, que passaram pelos processos de descascagem, secagem e estocagem. $\mathrm{Na}$ descascagem, também chamada de debastagem, é retirado o excesso de material externo da cana. Na secagem, a cana fica na posição vertical, dispostas como feixes. No final do processo, é feita a estocagem, onde a cana fica armazenada para que possa ser usada para as próximas etapas da confecção das palhetas.

É importante salientar que quanto mais tempo a cana ficar na estocagem, mais seca ela se manterá, o que possibilitará melhor qualidade para a confecção das palhetas. Algumas marcas utilizadas são: Loree, Madame Guis, Aleaude, Rigoti, Glotin e Berteloth.

\subsection{Pré-Goiva}

Com esta máquina, corta-se o tubo em 76 milímetros (mm) e extrai-se a madeira do interior do mesmo para que seja goivada, posteriormente (Figura 5). 


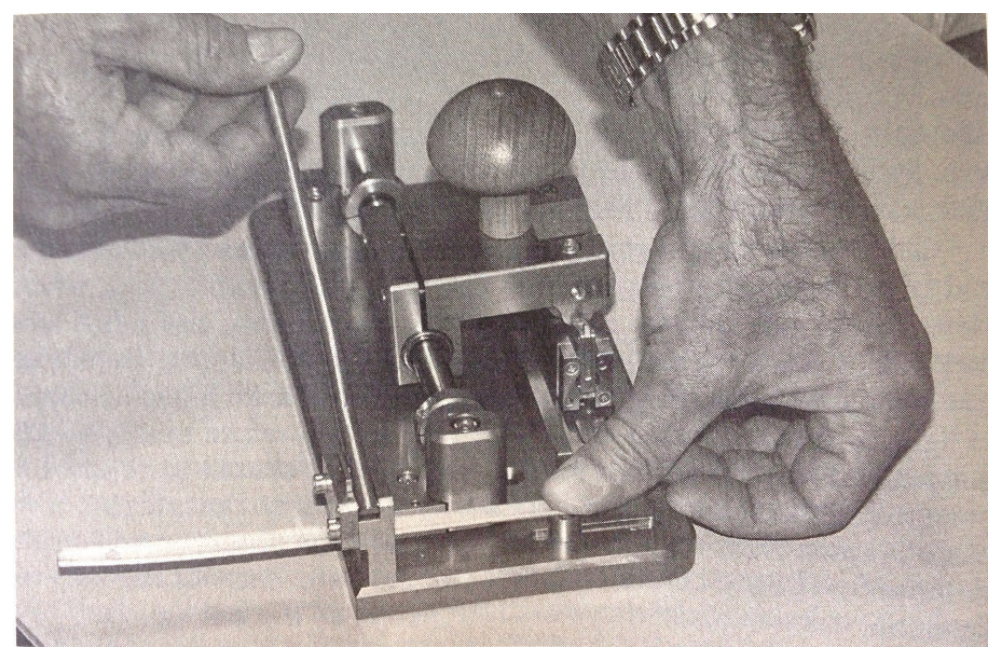

Figura 5: Pré-goiva (Fonte: http://images.google.com/).

\subsection{Goiva}

Com esta outra máquina, é retirado o excesso do interior da cana e o acabamento do processo de goivagem, onde já se tem a medida final para que a cana fique com a espessura de 56 a $60 \mathrm{~mm}$, variando de acordo com a espessura que se quer a cana (Figura 6).

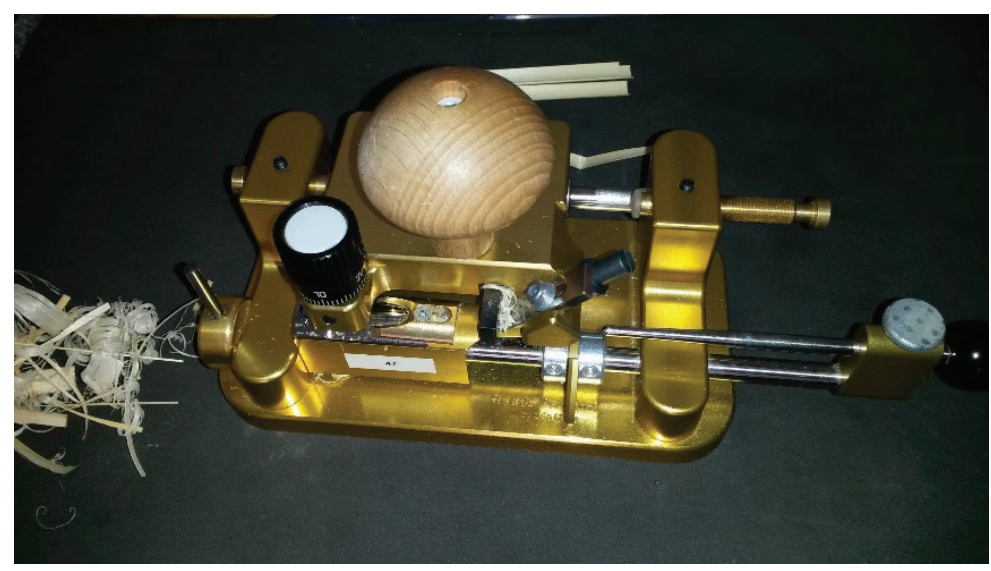

Figura 6: Goiva (Fonte: http://images.google.com/). 
Esses dois equipamentos, pré-goiva e goiva, são de alto custo, o que dificulta sua aquisição. Por esse motivo, muitos oboístas adquirem as canas previamente goivadas (Figura 7).

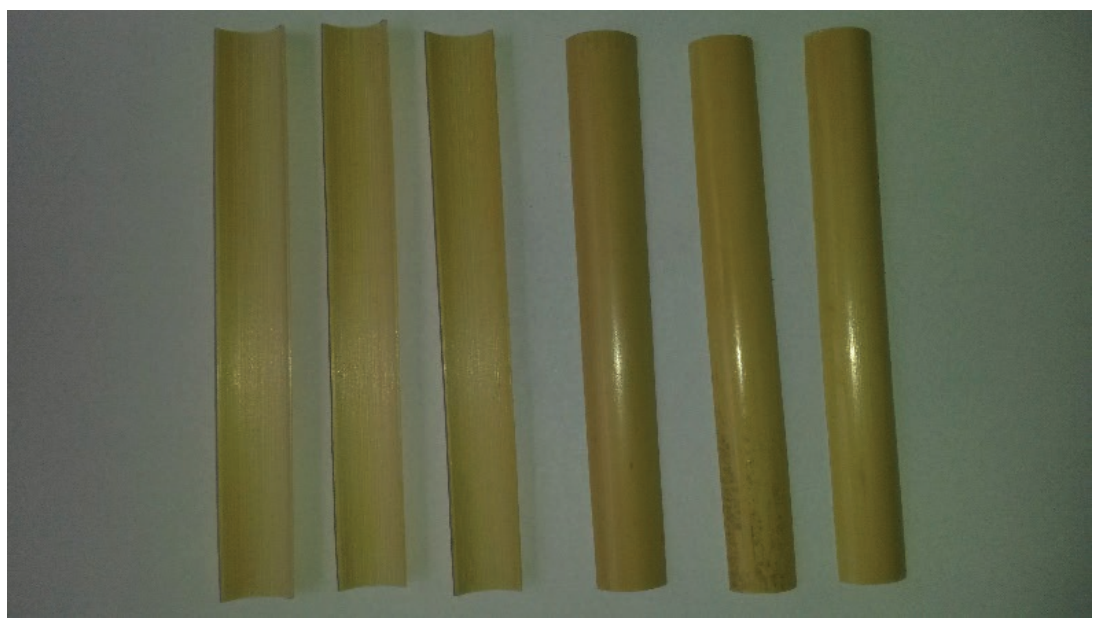

Figura 7: Canas goivadas (Fonte: acervo da autora).

\subsection{Micrômetro}

Este equipamento mede com precisão a espessura da cana por meio de um parafuso micrométrico. Também possui uma lingueta que possibilita medir a espessura de cada lâmina da palheta, separadamente, obtendo maior precisão também no momento da raspagem, possibilitando maior igualdade simétrica na espessura das lâminas (Figura 8). 


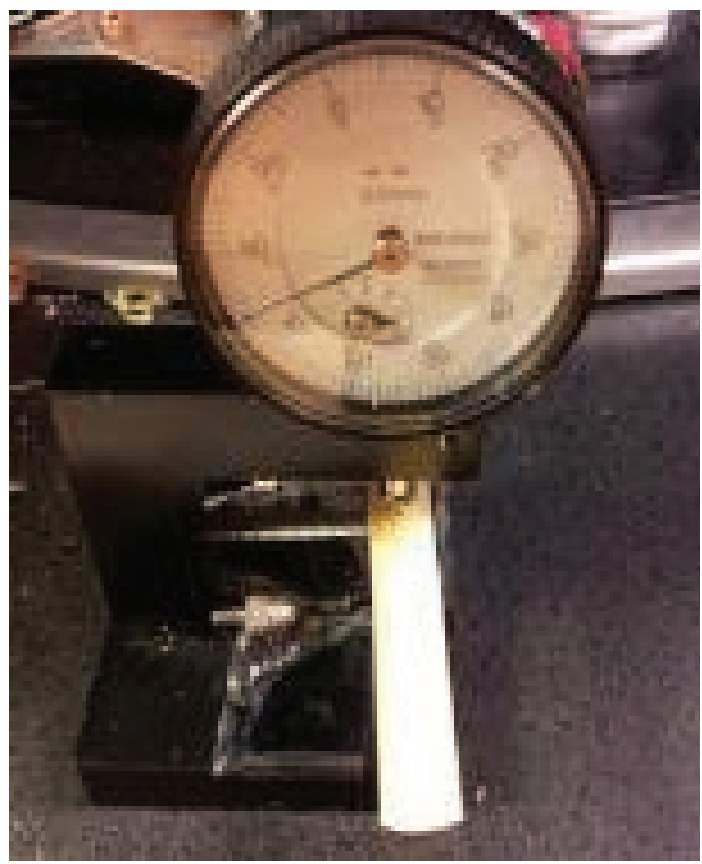

Figura 8: Micrômetro (Fonte: acervo da autora).

\subsection{Molde}

molde é um objeto de metal, pelo qual se coloca a cana a fim de se estabelecer o tamanho e as medidas padrões para a confecção das palhetas (Figura 9).

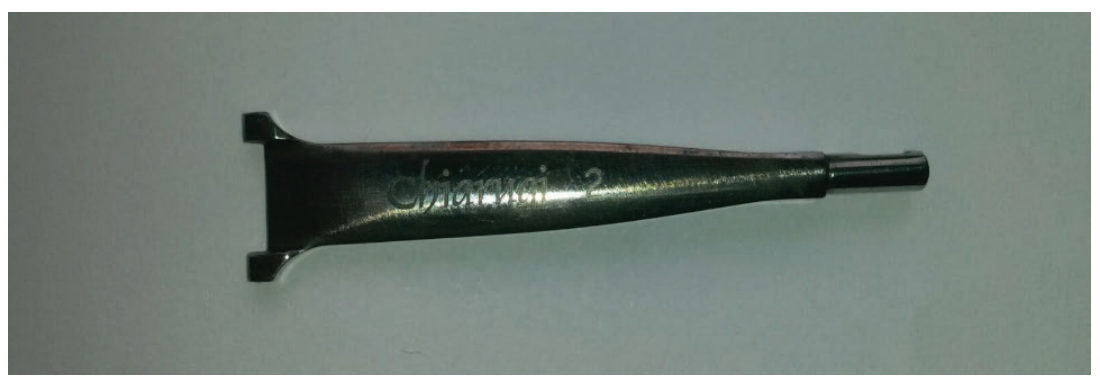

Figura 9: Molde Chiarugi n²2 (Fonte: acervo da autora). 


\subsection{Cabo do Molde}

- cabo é onde se coloca o molde para que a cana seja moldada (Figura 10).

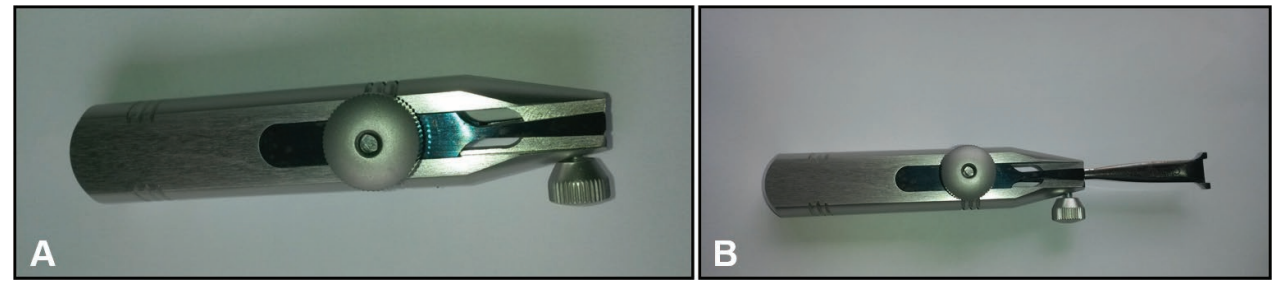

Figura 10: (A) Cabo do molde; (B) Cabo com o molde (Fonte: acervo da autora).

\subsection{Mandril}

mandril é colocado dentro do tubo. É utilizado desde o processo da amarração até o final da raspagem (Figura |1).

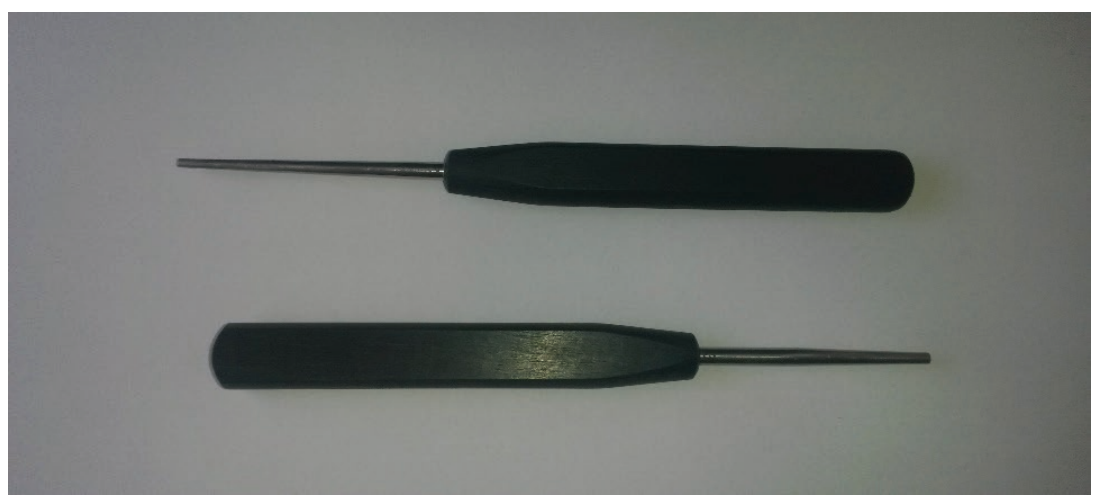

Figura 1 1: Modelos de Mandril (Fonte: acervo da autora). 


\subsection{Linha de nylon}

É usada para amarrar a cana por ser muito resistente (Figura 12).

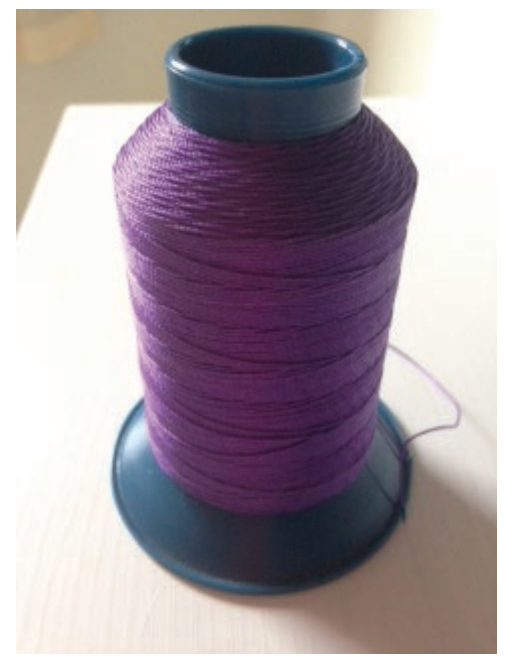

Figura 12: Linha de Nylon (Fonte: acervo da autora).

\subsection{Lingueta}

A lingueta é utilizada na raspagem. É colocada entre as duas lâminas da palheta para que se tenha maior apoio e precisão. Pode ser de madeira, plástico ou metal (Figura 13).

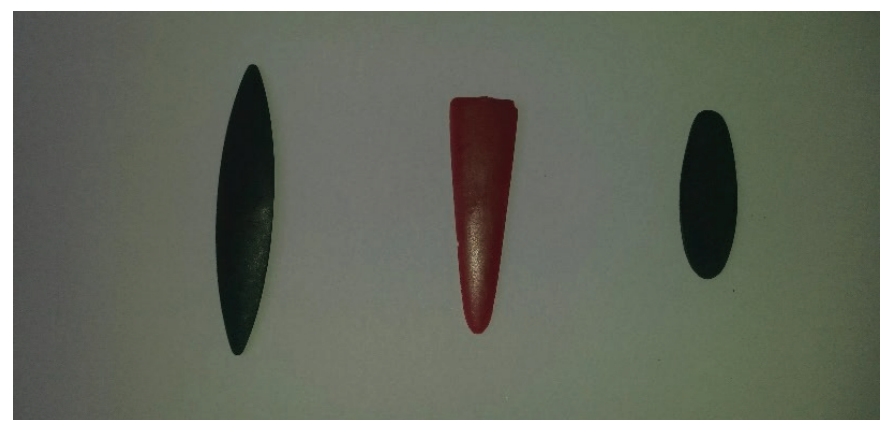

Figura 13: Lingueta de madeira, plástico e metal (Fonte: acervo da autora). 


\subsection{Tubo}

O tubo é feito de metal e a base onde é colocada no oboé é revestida com cortiça. Existem várias marcas e medidas de tubos. A escolha do tubo está relacionada à afinação do instrumento. Para instrumentos com tendências de afinação "alta", recomenda-se tubos menores; para instrumentos com tendências de afinação "baixa", tubos maiores. Os tubos são reutilizáveis, devendo-se lubrificar a cortiça com vaselina sólida ou manteiga de cacau para que tenham maior durabilidade (Figura 14).

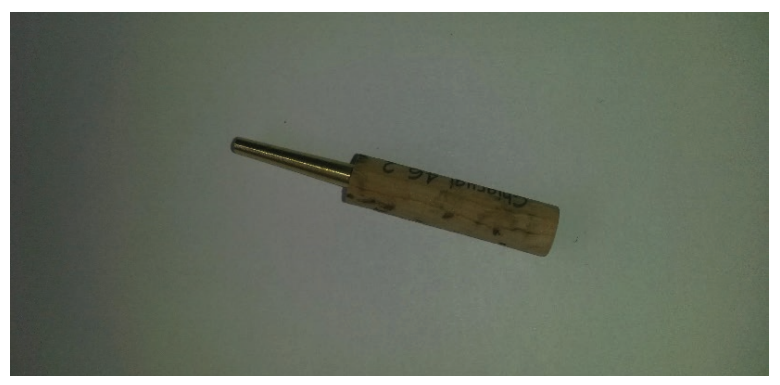

Figura 14: Tubo (Fonte: acervo da autora).

\subsection{Pedra de afiar}

São pedras utilizadas para afiar as facas utilizadas na raspagem das canas. A mais usada é a Pedra Japonesa. Recomenda-se utilizar pedras de gramatura 1000 (Figura 15).

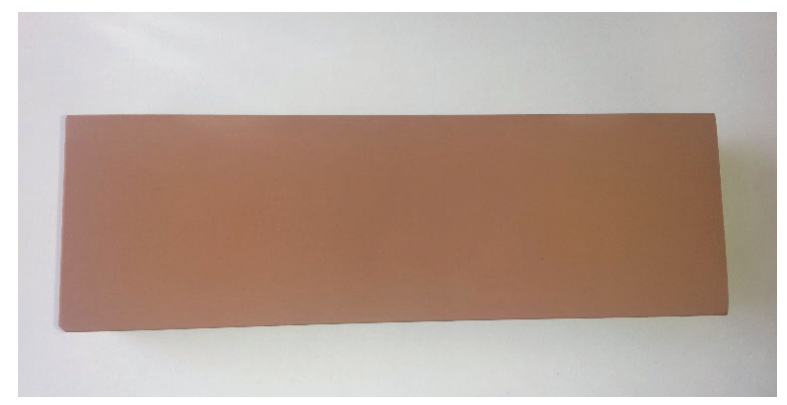

Figura 15: Pedra para afiar (Fonte: acervo da autora). 


\subsection{Assentador de fios}

Mantém o fio da faca afiada pela pedra, anteriormente. Possui uma base de madeira e duas superfícies das laterais revestidas com couro, um lado mais abrasivo e outro menos (Figura 16).

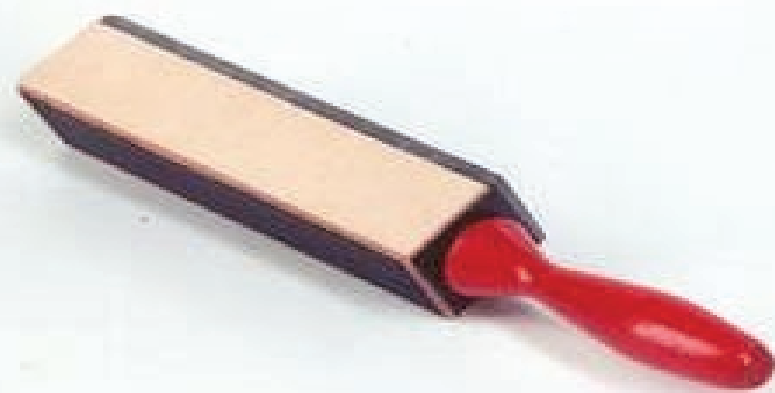

Figura 16: Assentador de fios (Fonte: acervo da autora).

\subsection{Paquímetro}

É uma régua graduada em mm, usada para medir o comprimento da palheta (Figura 17).

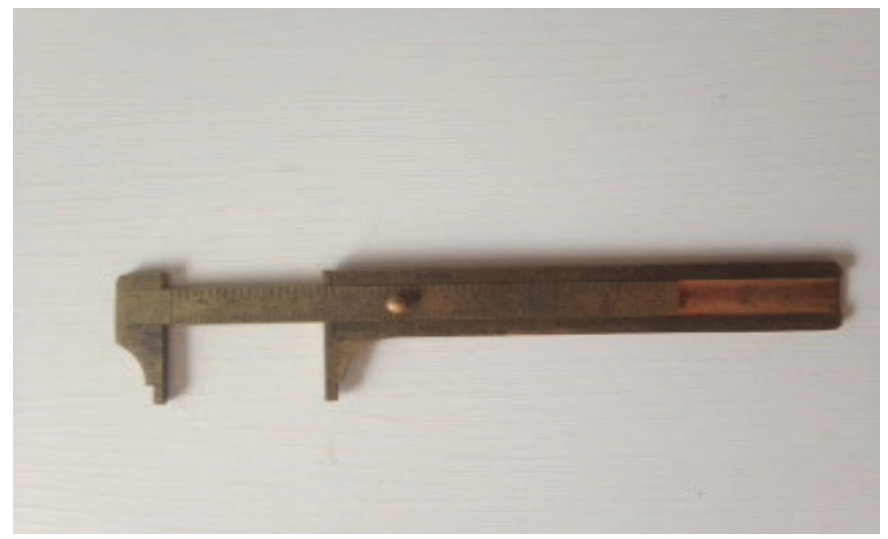

Figura 17: Paquímetro (Fonte: acervo da autora). 


\subsection{Arame}

É usado também na amarração da cana ao tubo e para se obter maior abertura das duas lâminas quando a ponta da palheta fica muito fechada, dificultando a passagem do ar. $\bigcirc$ arame mais indicado é o de latão com espessura de $0.35 \mathrm{~mm}$ por ser mais resistente, porém flexivel (Figura 18).
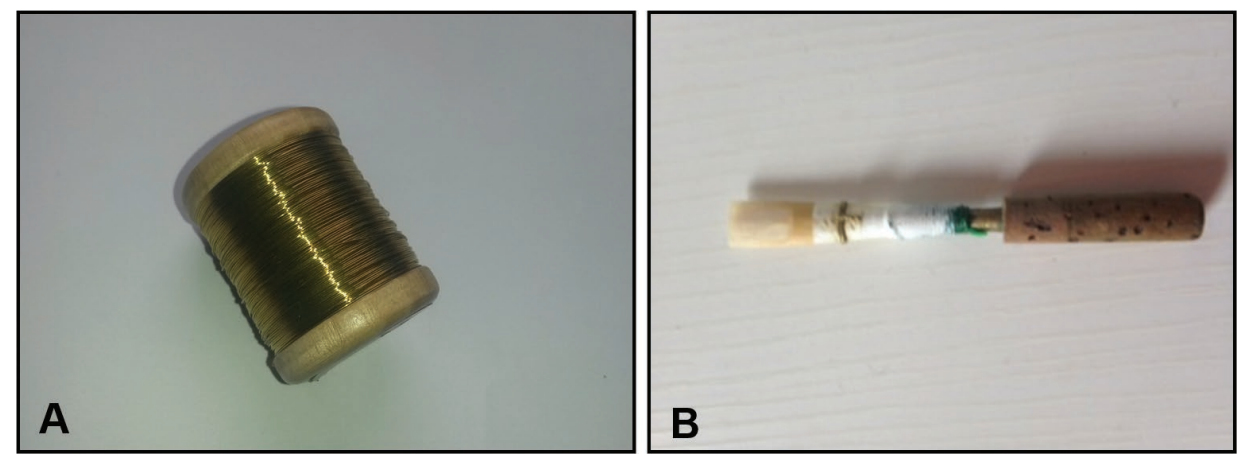

Figura 18: (A) Rolo de arame; (B) Arame abrindo a palheta (Fonte: acervo da autora).

\subsection{Alicate de bico}

alicate de bico é utilizado para fixar o arame colocado na palheta (Figura 19).

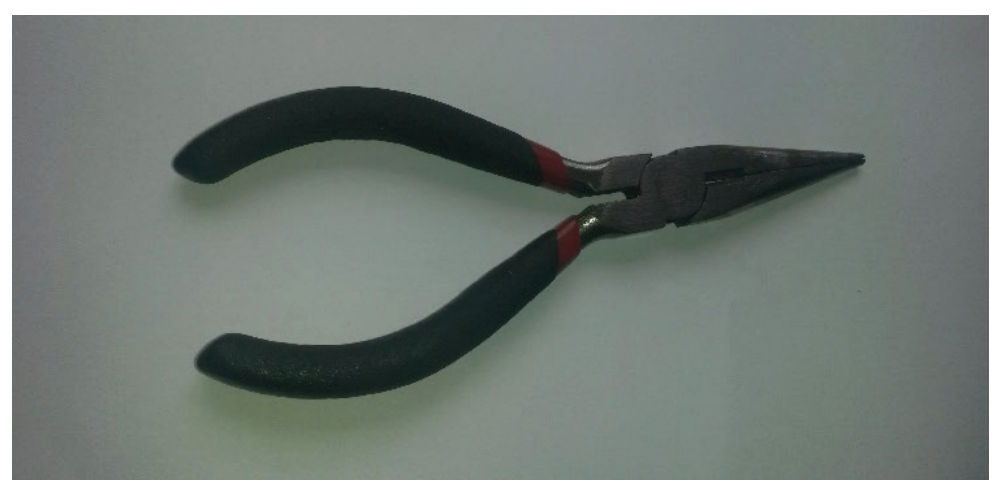

Figura 19: Alicate de bico (Fonte: acervo da autora). 


\subsection{Bloco de corte e Guilhotina}

bloco de corte e a guilhotina são usados para cortar a ponta da palheta (Figura 20).
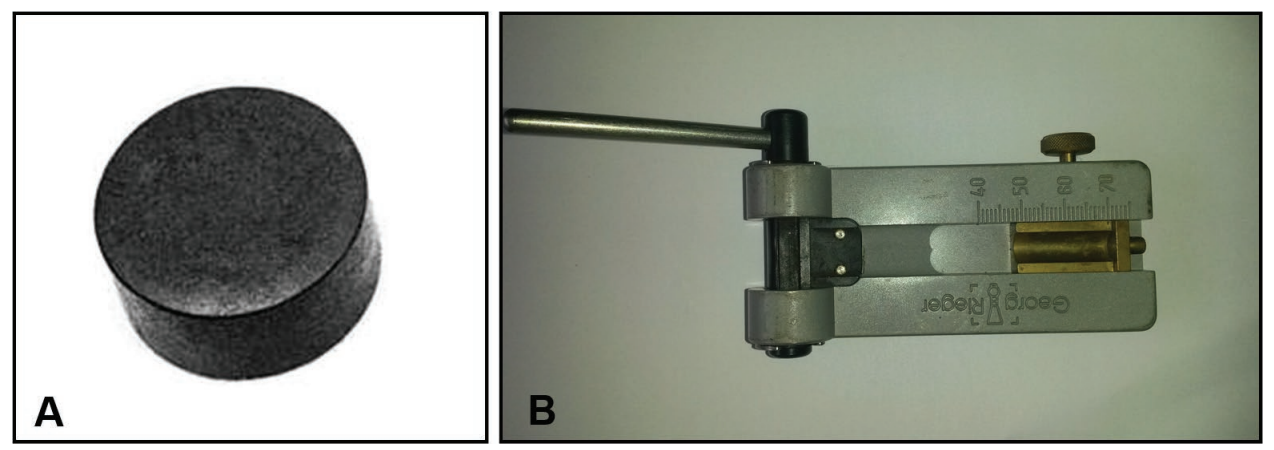

Figura 20: (A) Bloco de corte; (B) Guilhotina. (Fonte: acervo da autora).

\subsection{Guia ou marcador}

Coloca-se a cana moldada na guia para se obter a marcação do meio da cana com precisão (Figura 21 ).

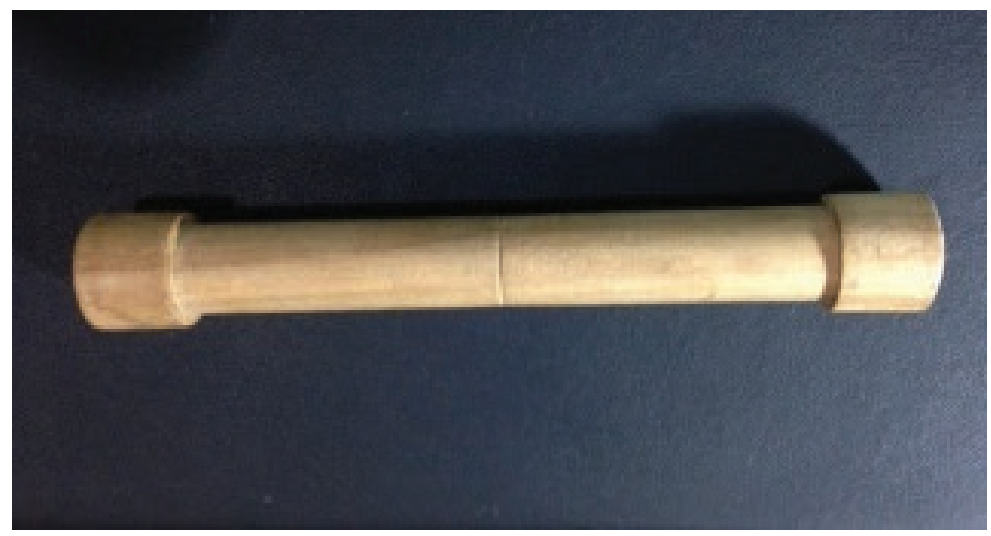

Figura 21: Guia ou marcador (Fonte: acervo da autora). 


\subsection{Faca}

A faca é a ferramenta responsável pela raspagem da cana desde a retirada do verniz até o minucioso acabamento da ponta. É importante que esteja bem afiada, porém deve-se tomar muito cuidado ao manuseá-la, pois se trata de objeto muito cortante.

Existem dois modelos de lâminas:

- Lâmina de chanfro simples ou oblíquo;

- Lâmina de chanfro duplo ou côncava.

A faca de chanfro simples é mais indicada para retirar o verniz da cana e iniciar a raspagem. A faca de chanfro duplo é utilizada na raspagem da ponta e no acabamento da palheta (Figura 22).

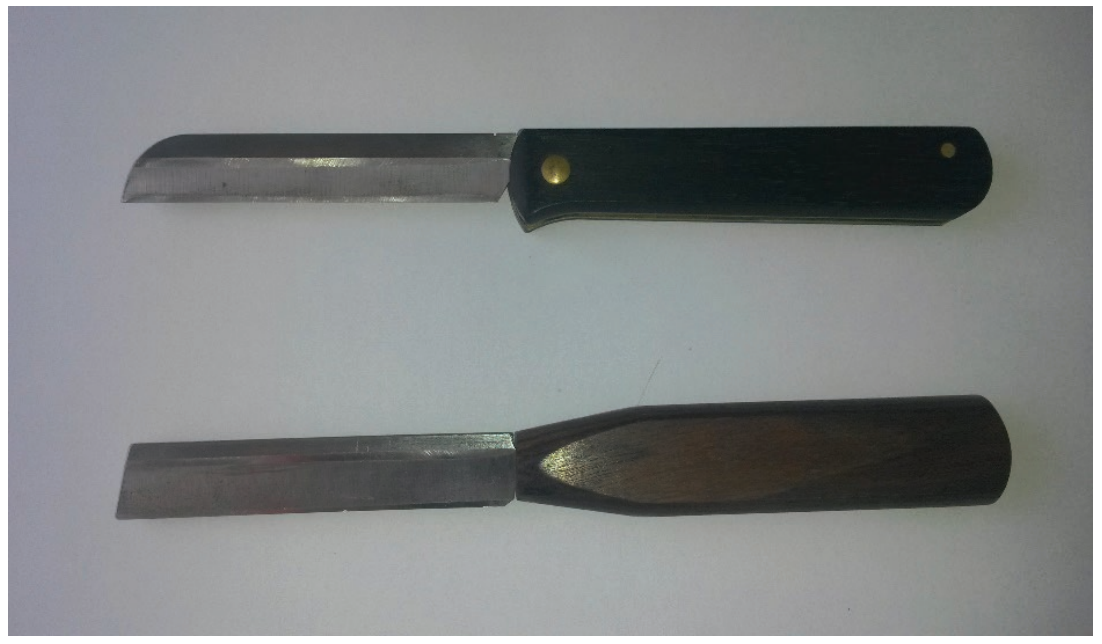

Figura 22: Facas de chanfro duplo e simples. (Fonte: acervo da autora). 


\section{19 Borracha de Látex}

É utilizada no processo da amarração para que as lâminas da palheta mantenham-se alinhadas no momento da amarração (Figura 23).

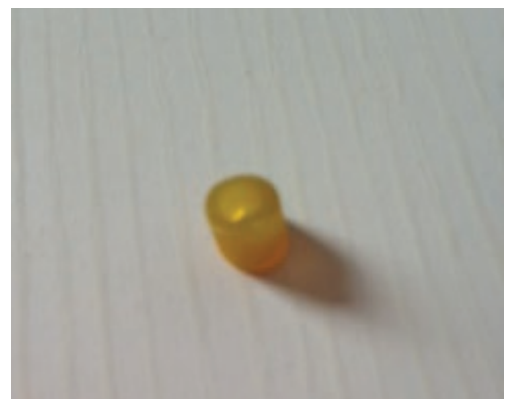

Figura 23: Borracha de látex (Fonte: acervo da autora).

\subsection{Lixa d’água}

A lixa é um papel com material de superfície abrasiva, utilizada para dar acabamento às canas, após serem moldadas. A gramatura ideal para que a cana seja lixada, pode variar de 400 a 1200, dependendo da dureza da cana. Podem ser encontradas em lojas de materiais de construções (Figura 24).

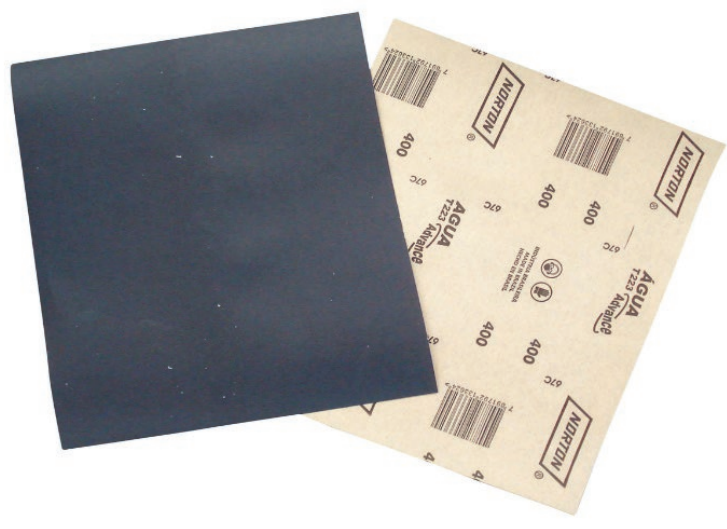

Figura 24: Lixa d'água. (Fonte: acervo da autora). 


\section{Moldagem}

A moldagem é a etapa onde a cana é colocada no molde e terá o aspecto de "canoa", como mostra a Figura 25.

Figura 25: Cana goivada e moldada (Fonte: acervo da autora).

Existem vários modelos e medidas de moldes. A escolha do molde a ser usado deve estar relacionada com o tipo de raspagem usada pelo oboísta. As siglas XN e as colunas que se situam à sua direita correspondem às medidas dos moldes para a raspagem alemã, consequentemente, as da esquerda são as possiveis medidas para o raspado americano. A Figura 26 mostra uma tabela de medidas para as raspagens alemã e americana (norte-americana). 


\begin{tabular}{c|c|c|c|c|c|c|c|c|}
\hline & $-\mathrm{IN}$ & $\mathrm{G}$ & -1 & 1 & $\mathrm{XN}$ & $\mathrm{R}$ & -2 & 2 \\
\hline $\mathrm{A}$ & 6.9 & 7.0 & 7.0 & 7.0 & 7.0 & 7.4 & 7.3 & 7.5 \\
\hline $\mathrm{B}$ & 6.5 & 6.5 & 6.6 & 6.7 & 6.8 & 6.8 & 6.9 & 7.0 \\
\hline $\mathrm{C}$ & 5.8 & 5.9 & 5.9 & 6.0 & 6.1 & 6.0 & 6.2 & 6.4 \\
\hline $\mathrm{D}$ & 4.8 & 4.7 & 4.9 & 5.0 & 5.0 & 4.9 & 5.2 & 5.2 \\
\hline $\mathrm{E}$ & 3.2 & 3.2 & 3.3 & 3.3 & 3.3 & 3.4 & 3.4 & 3.5 \\
\hline & & \\
-1 \\
-1
\end{tabular}

Figura 26: Tabela de medidas para moldes (Fonte: Ledet, 2008).

Para que a cana seja moldada, é necessário que a mesma fique dentro de um copo com água até que ela desça ao fundo do copo (Figura 27).
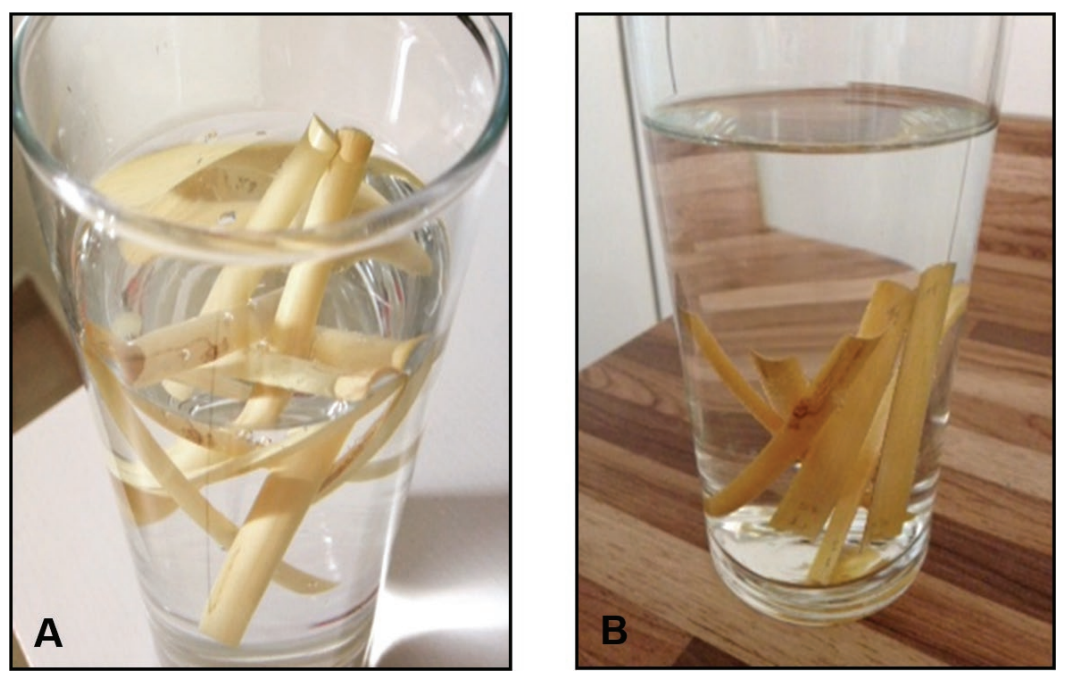

Figura 27: (A) Cana recém-molhada para ser moldada; (B) Cana pronta para ser moldada (Fonte: acervo da autora). 
Após esse procedimento, retira-se a cana da água e dobrase ao meio, obtendo-se duas lâminas, porém ainda juntas. Se a cana não estiver molhada o suficiente, pode rachar ou quebrar quando for dobrada para ser colocada no molde (Figura 28).

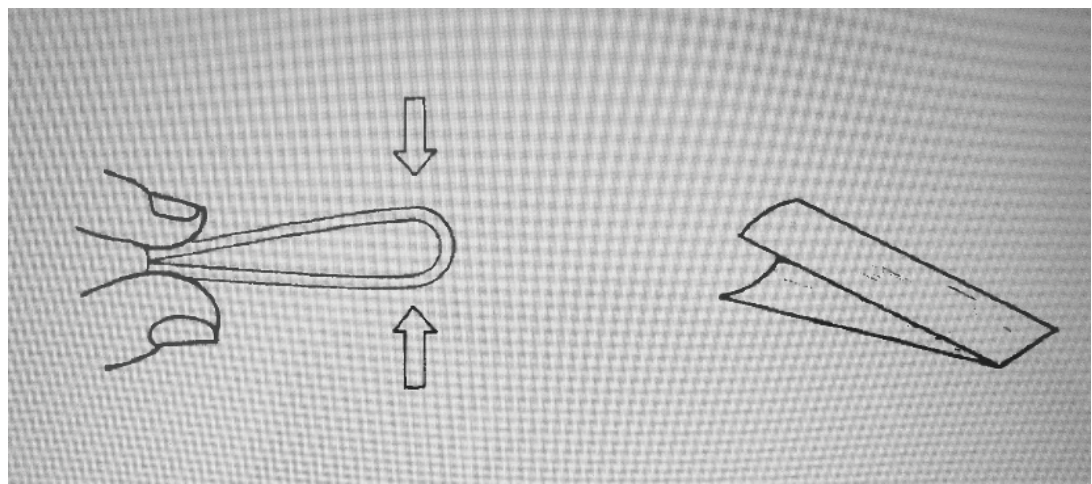

Figura 28: Cana dobrada ao meio (Fonte: Neuhaus et al., 1998).

Em seguida, como mostra a Figura 29, cortam-se, com um estilete, as duas quinas da extremidade superior da lâmina que ainda estão conectadas para que estas se encaixem no molde (Neuhaus et al., 1998, pag.35).

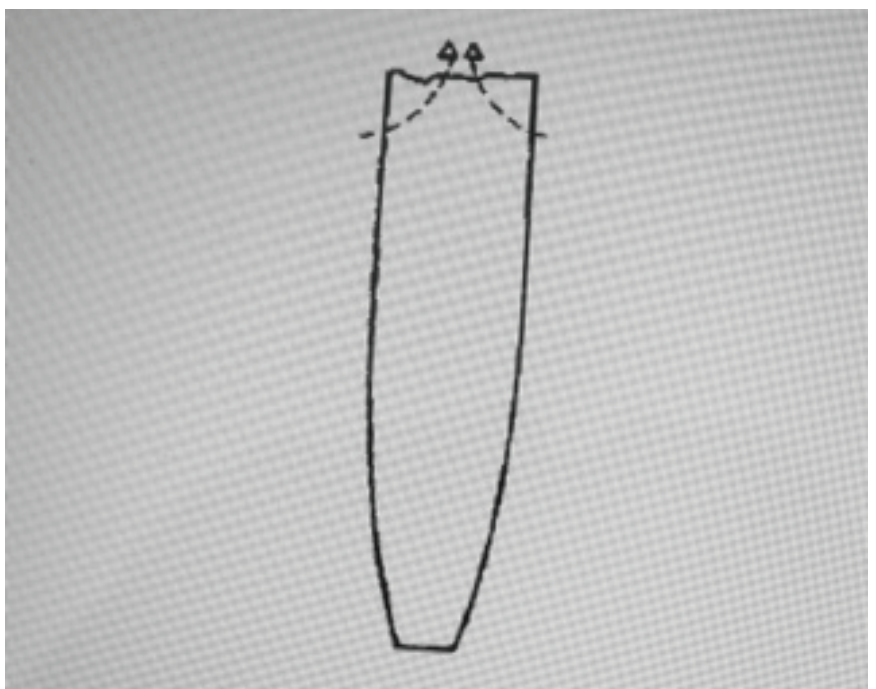

Figura 29: Corte das laterais da cana (Fonte: Neuhaus et al., 1998). 
Posteriormente, a cana deve ser presa pela parte inferior ao cabo, onde as lâminas estão separadas. Lembrando que o cabo e o molde compõem uma peça única, depois de unidos. Observar se as lâminas estão centradas no molde, e que seus lados coincidam perfeitamente (Figura 30).

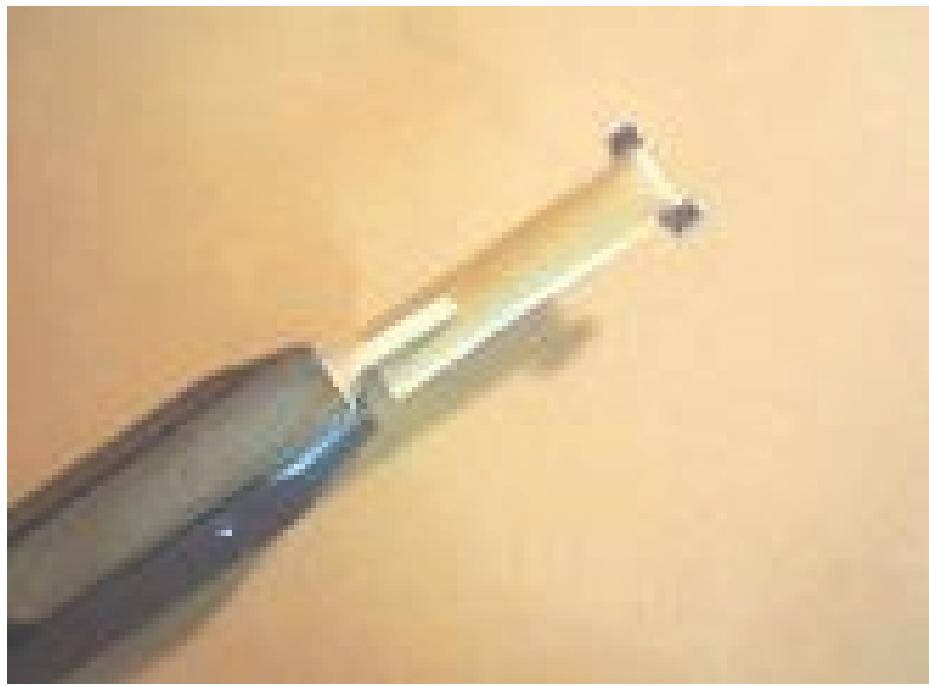

Figura 30: Cana no molde (Fonte: Making Oboe Reeds, Shalita, 2003).

moldar, de fato, tem início nesse momento, ao se cortar as laterais da cana com o estilete, sempre da parte superior para a inferior do molde. Observar sempre se as lâminas do estilete estão cortando com facilidade. Caso não estejam, devem ser trocadas, pois o contato que ocorre entre o molde e a lâmina, ambos de metal, estraga o fio de corte do estilete facilmente. Além do fato de que com a força excessiva para cortar a cana, a mesma pode sair do lugar. Feito esse procedimento, retira-se a cana do molde, e com o auxílio de uma lixa d'água de gramatura 400, lixa-se as laterais recém-cortadas da cana, tirando os excessos e deixando-a pronta para ser amarrada. 


\section{Amarração}

Esta é a etapa em que a cana será fixada ao tubo. A amarração deve proceder levando-se em consideração a raspagem que será realizada posteriormente. Serão necessários os seguintes materiais:

- Linha de nylon

- Tubo

- Cana goivada e moldada

- Copo com água natural

- Mandril

- Alicate de bico

- Guia

- Linha de costura ou borracha de látex

- Tesoura

- Lápis

- Mesa

- Estilete 
É importante que todo o procedimento seja realizado sobre uma mesa, cuja superfície tenha espaço suficiente para o manuseio dos materiais.

Colocar a cana moldada em um copo com água até que a cana umedeça e decante no fundo do copo, repetindo o mesmo procedimento feito para a moldagem da cana. Em seguida, separar os materiais para a amarração já mencionados anteriormente. Após retirar a cana da água, juntar as duas extremidades da mesma, que estão desconectadas e amarrá-las com uma linha de costura ou uma borracha de látex. A amarração deve proceder de acordo com a raspagem que será feita. No caso da raspagem alemã, as lâminas da cana devem ser posicionadas exatamente na mesma direção uma da outra. Em seguida, coloca-se a borracha de látex para mantê-las juntas (Figura 31 ).

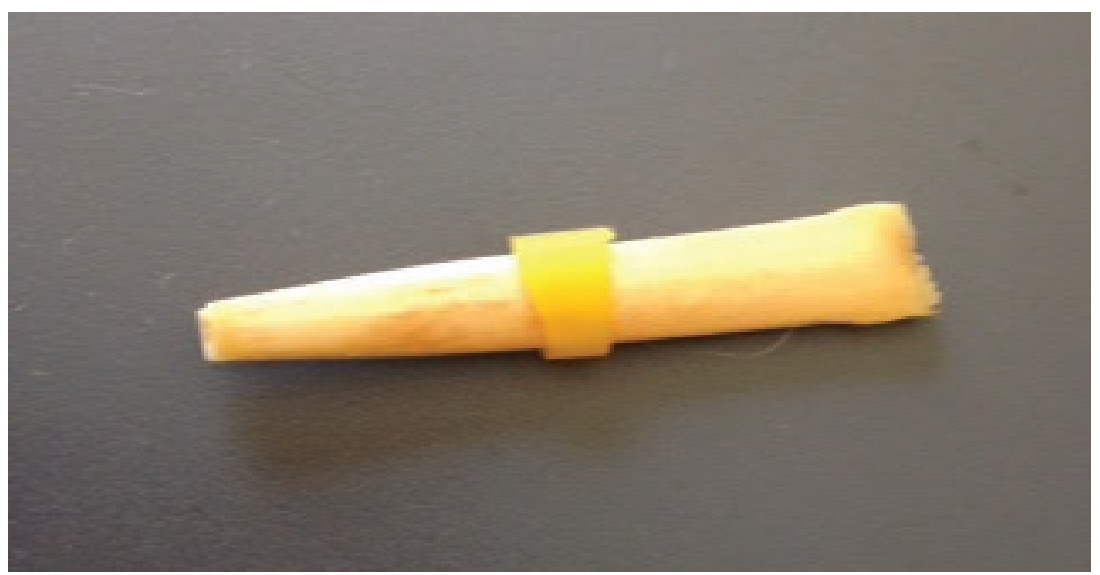

Figura 3 1: Cana com borracha de látex (Fonte: acervo da autora). 
Na raspagem americana, é necessário ocorrer o overlap quando as lâminas são unidas, ou seja, uma lâmina deve ficar sobreposta a outra, mas ligeiramente desalinhada. Esse procedimento denominado overlap é utilizado para reter a vibração excessiva das lâminas (Figura 32).

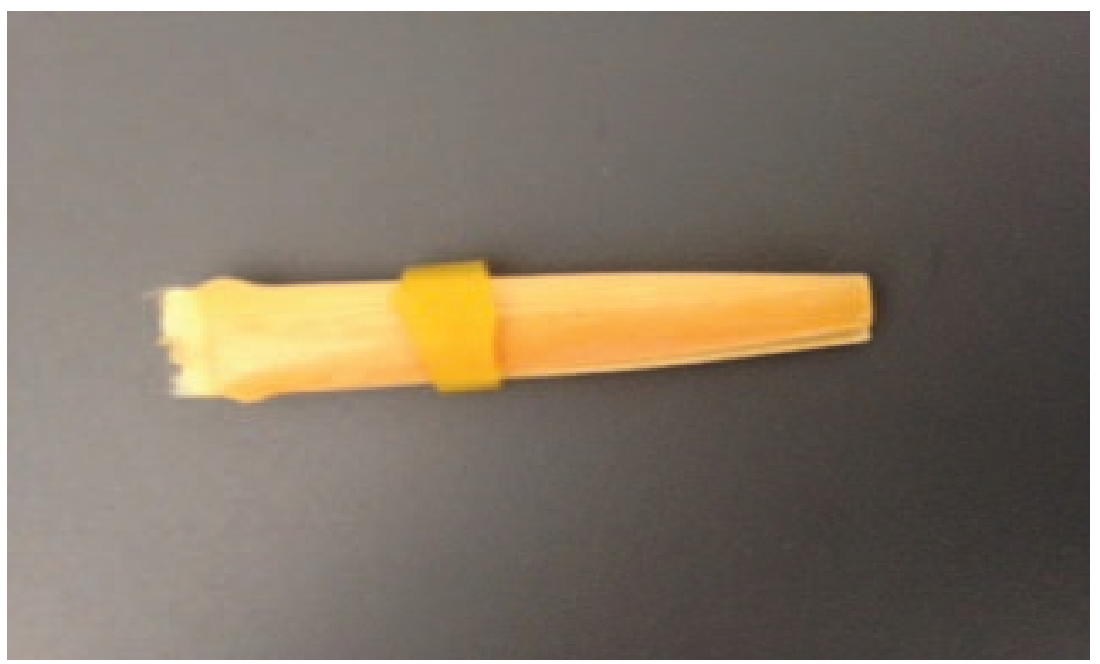

Figura 32: Cana com overlap (Fonte: acervo da autora).

Colocar a cana dobrada na extremidade de metal do tubo e com o auxílio de um paquímetro ou régua, medir $75 \mathrm{~mm}$ do final do tubo até a região da cana que ainda não foi cortada. Essa medida referese à raspagem alemã. Para a raspagem americana, a cana deve ser amarrada ao tubo com $73 \mathrm{~mm}$ de comprimento. $\bigcirc$ tubo usado para os exemplos deste trabalho foi o da marca Chiarugi 46.2 (Figura 33). 


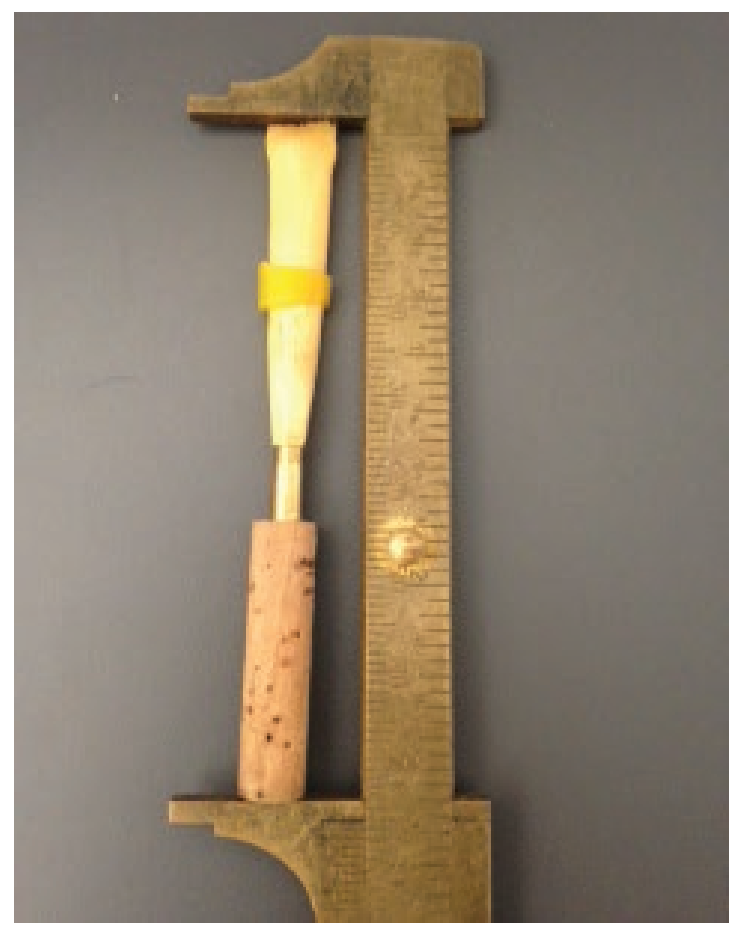

Figura 33: Cana no paquímetro medindo 75 mm (Fonte: acervo da autora).

Em seguida, marcar na lateral da cana o final do tubo com um lápis, e depois, colocar o tubo no mandril sem perder a medida já feita, como mostra a Figura 34.
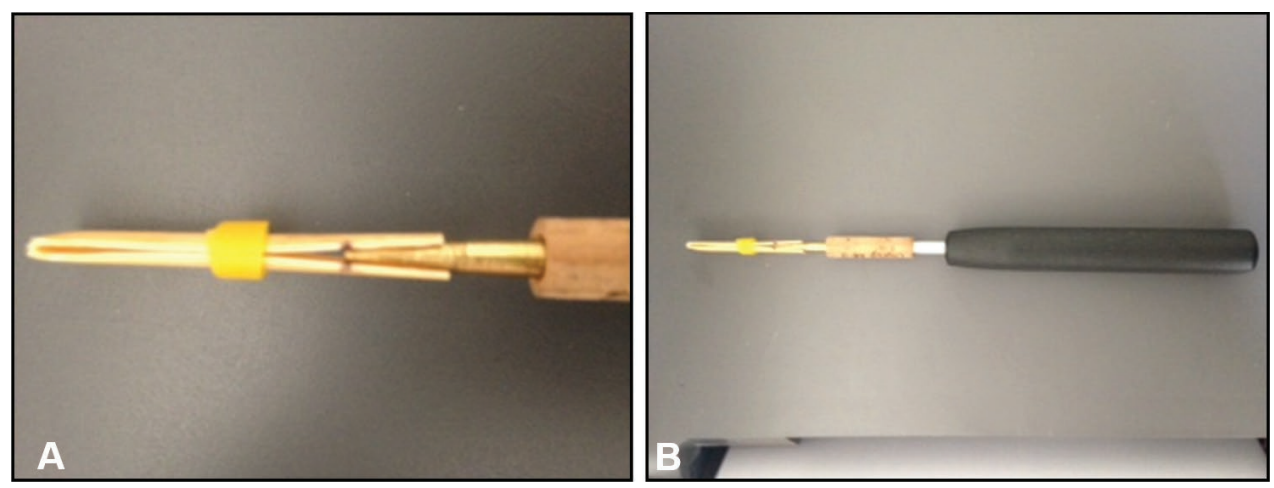

Figura 34: (A) Marcação do final do tubo; (B) Cana marcada no mandril (Fonte: acervo da autora). 
Amarrar a linha de nylon em uma das pernas da mesa ou em um gancho onde se possa ter firmeza no momento de puxar a linha. Sugerimos utilizar a linha em um carretel pequeno para facilitar a amarração. Segurar o carretel com a mão direita, posicionando a linha entre os dedos indicador e médio (Figura 35).

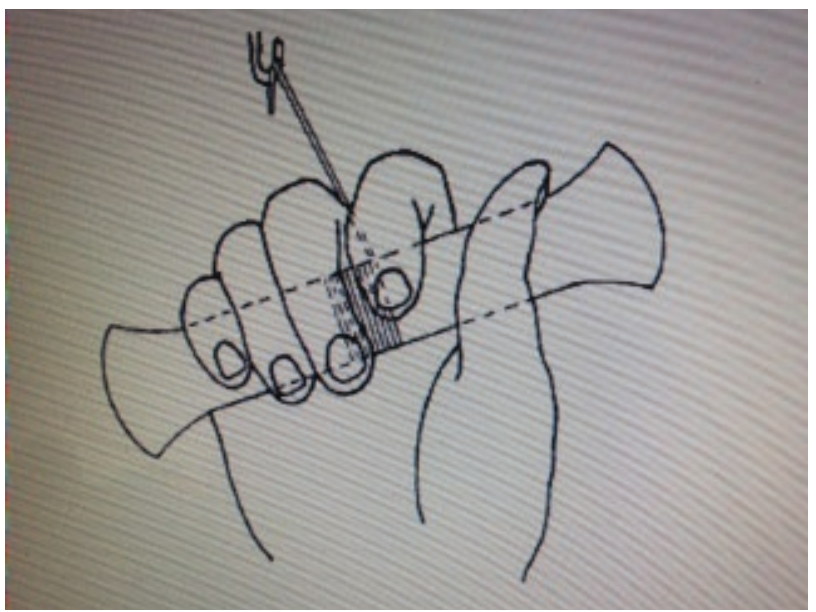

Figura 35: Mão segurando o carretel e a linha (Fonte: Neuhaus et al., 1998).

Esticar a linha por 15 a 20 centímetros permitindo que tenha espaço suficiente para fazer a volta no tubo e na cana. Estes devem ser seguros juntamente com o mandril pela mão esquerda (Figura 36).
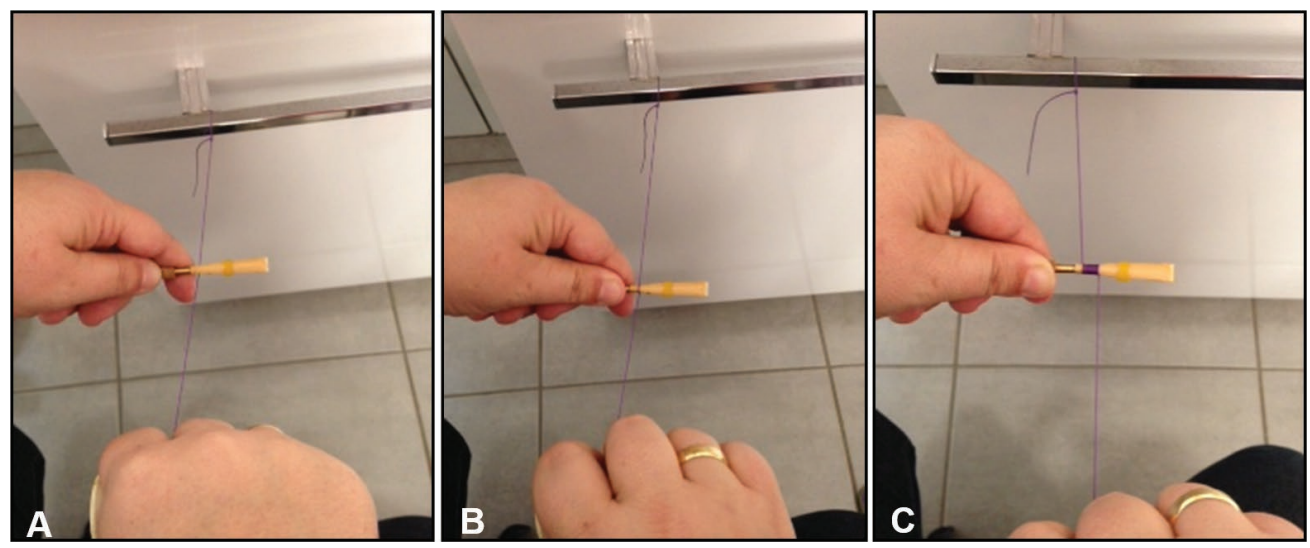

Figura 36: Amarrando a cana (Fonte: acervo da autora). 
Posicionar a cana que está no mandril em cima da linha e, com a mão direita, dar três a quatro voltas chegando até a marca que foi feita indicando o final do tubo, com o intuito de fechar as laterais. Durante cada volta, certificar-se de que a cana está centrada no tubo, e que a linha está firme e tensionada, porém sem força demasiada para que a linha não arrebente e se perca tudo o que foi feito. Em seguida, deve-se girar a linha na diagonal, por cima da linha já amarrada (Figura 37).

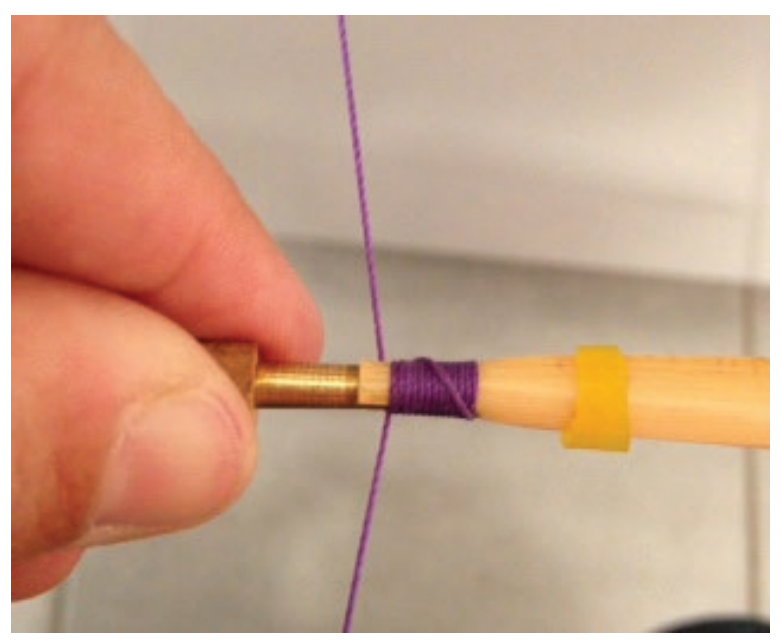

Figura 37: Virada da linha (Fonte: acervo da autora).

Continuar girando a linha até chegar à distância de $1 \mathrm{~mm}$ ao final do tubo para dar os nós e finalizar a amarração. Manter a mão esquerda bem firme tencionando a linha e com a mão direita serão dados os nós. Posicionar a linha no meio da palma da mão direita, girar a linha por cima da cana no sentido anti-horário, laçar a cana e puxar a linha para dar o nó. Este será o primeiro de quatro nós (Figura 38). 

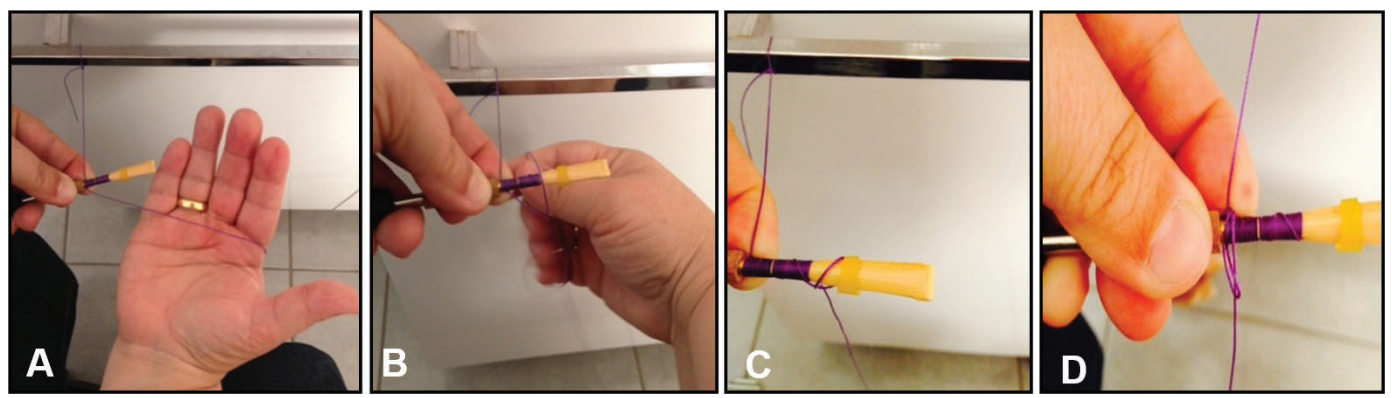

Figura 38: Fazendo o nó na palheta (Fonte: acervo da autora).

Repetir o mesmo procedimento, o que resultará no segundo nó. Em seguida, cortar a linha que está sendo segurada pela mão esquerda com uma tesoura ou estilete, deixando uns $5 \mathrm{~mm}$ de linha solta (Figura 39).
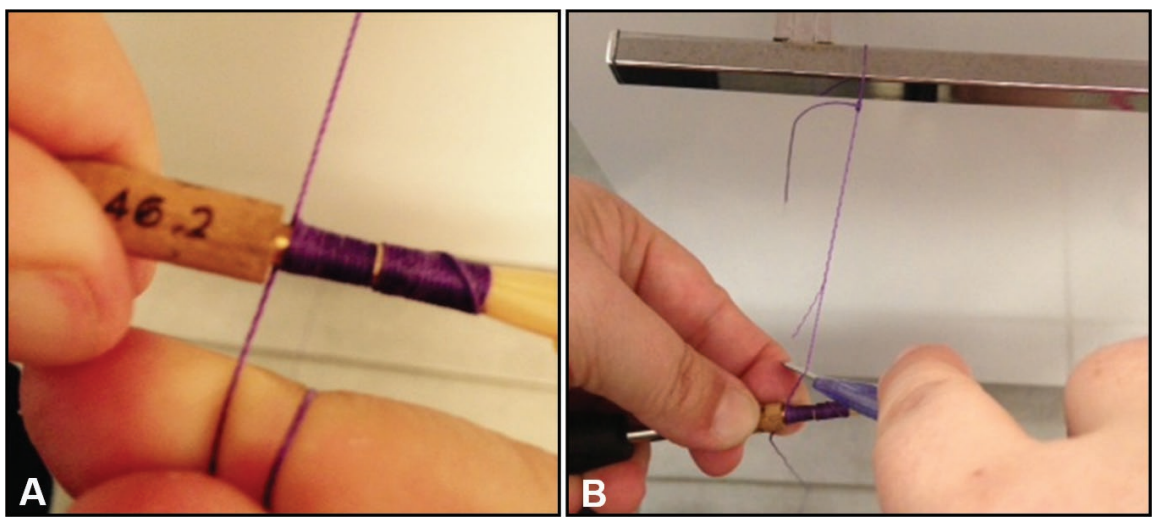

Figura 39: (A) Cana com dois nós; (B) Cortando a linha com estilete (Fonte: acervo da autora). 
Fazer mais dois nós para que fique bem amarrado e a linha não corra o risco de se soltar, finalizando assim, a amarração (Figura 40).

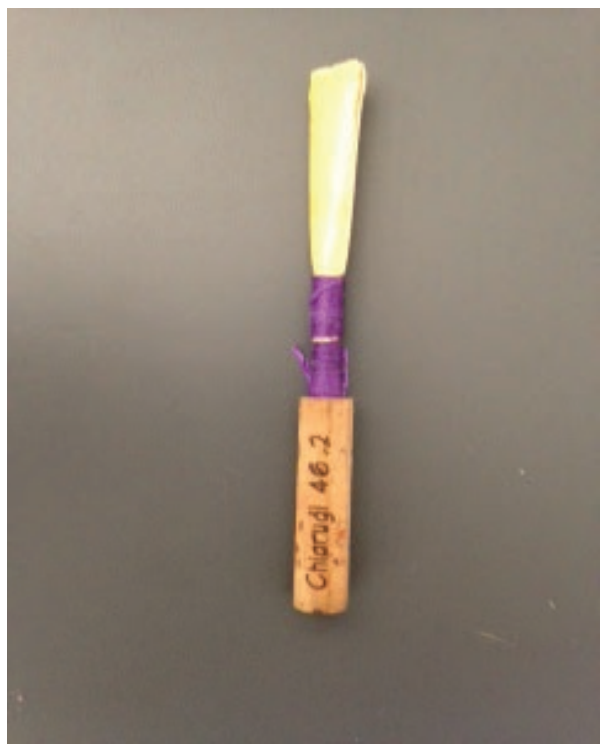

Figura 40: Cana amarrada (Fonte: acervo da autora).

\section{Raspagem}

Neste estágio da confecção da palheta, será tirado o verniz natural da cana em algumas regiões específicas, possibilitando a vibração das duas lâminas concomitantemente. Alguns fatores devem ser considerados para que se tenha êxito na raspagem: facas de qualidade e bem afiadas, precisão nas medidas, simetria entre as duas lâminas e boa luminosidade no local onde ocorrerá a raspagem. Atualmente, as escolas de raspagem se fundiram e as opções de raspagem ficam, primordialmente, a critério do oboísta. Porém, dois raspados destacamse entre os demais: o alemão e o americano. Neste trabalho será descrito apenas o raspado alemão na maneira particular da autora, havendo assim, outras possibilidades no procedimento da raspagem. 
Na raspagem alemã, têm-se como base os seguintes materiais:

- Tubo Chiarugi: 46.2 mm (podendo ser também tubo Lorée 46 $\mathrm{mm})$.

- Molde: Chiarugi (podendo ser também o Albrecht Meyer, H26, H49 e RDC-2).

- Amarração: 75 mm sem overlap.

- Lingueta

- Mandril

- Paquímetro

- Faca

Na Figura 41, estão indicadas as partes onde a cana será raspada. 

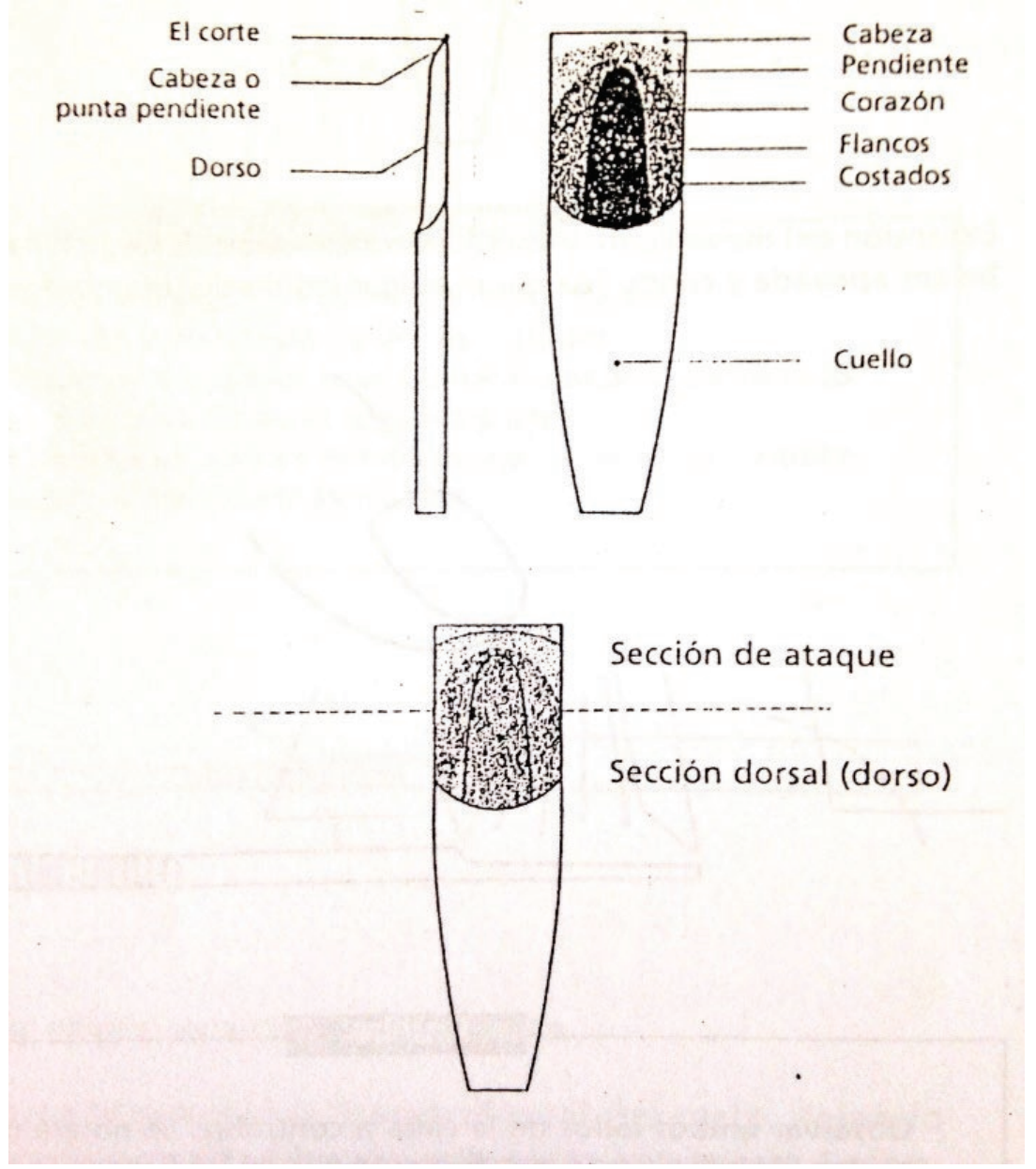

Figura 4 1: Partes da cana (Fonte: Neuhaus et al., 1998).

Antes de iniciar a raspagem, é necessário que a ponta da cana seja colocada na água por cerca de cinco minutos. Não molhar a linha com a qual a cana foi amarrada (Figura 42). 


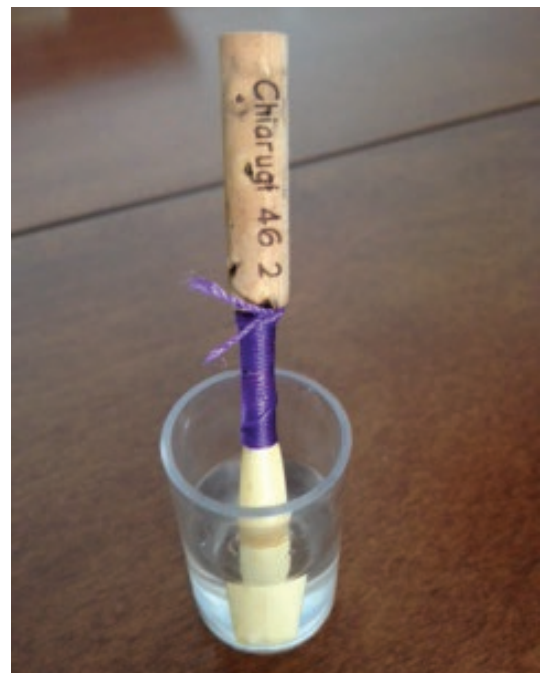

Figura 42: Molhando a ponta da palheta (Fonte: acervo da autora).

Em seguida, medir 6 mm da ponta e marcar com um lápis. Raspar a ponta tirando o verniz da cana, apoiando sempre com o de do indicador. A Figura 43 mostra o antes e o depois do processo mencionado.

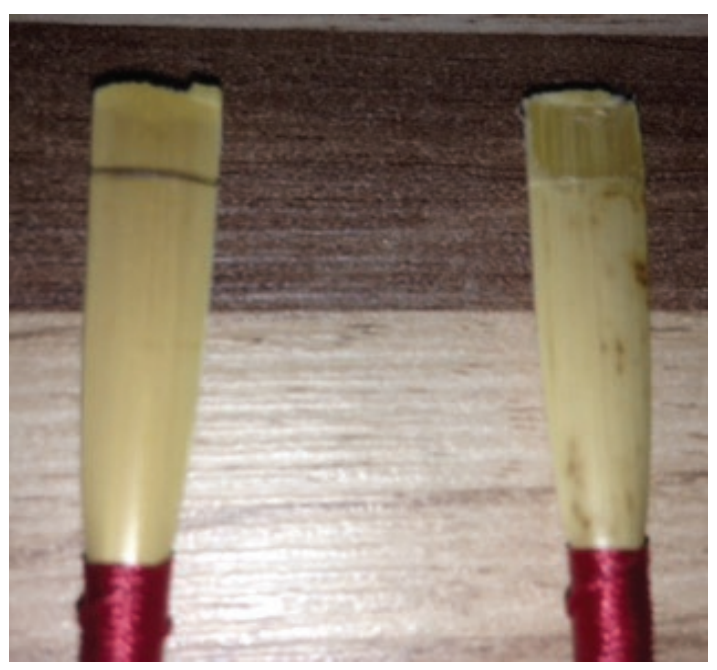

Figura 43: Marcação e raspagem da ponta. 
Após este procedimento, molhar a cana novamente e cortar a ponta para obter as duas lâminas desconectadas. Colocar a cana na guilhotina e medir $71 \mathrm{~mm}$ do final do tubo até a ponta. Se usar o bloco de corte, medir com o paquímetro ou com a régua, para que se tenha exatidão na medida (Figura 44).
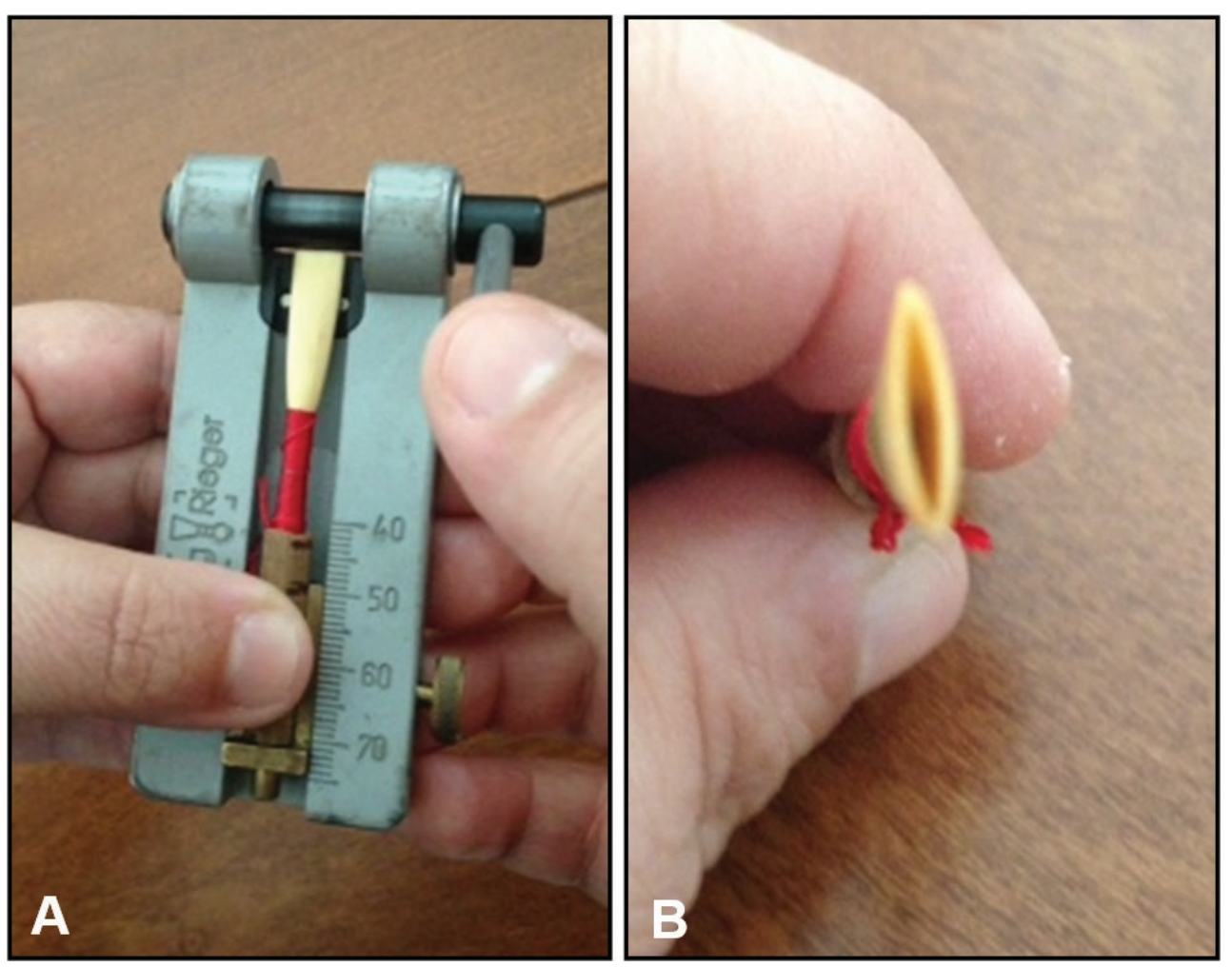

Figura 44: (A) Cortando a ponta; (B) Ponta aberta (Fonte: acervo da autora). 
Outra maneira de se obter a abertura da ponta da cana é usando uma lixa d'água de gramatura 600. Para isso, coloque a lixa em cima da mesa, segure a ponta da cana com o dedo indicador e puxe na direção do corpo (Figura 45).
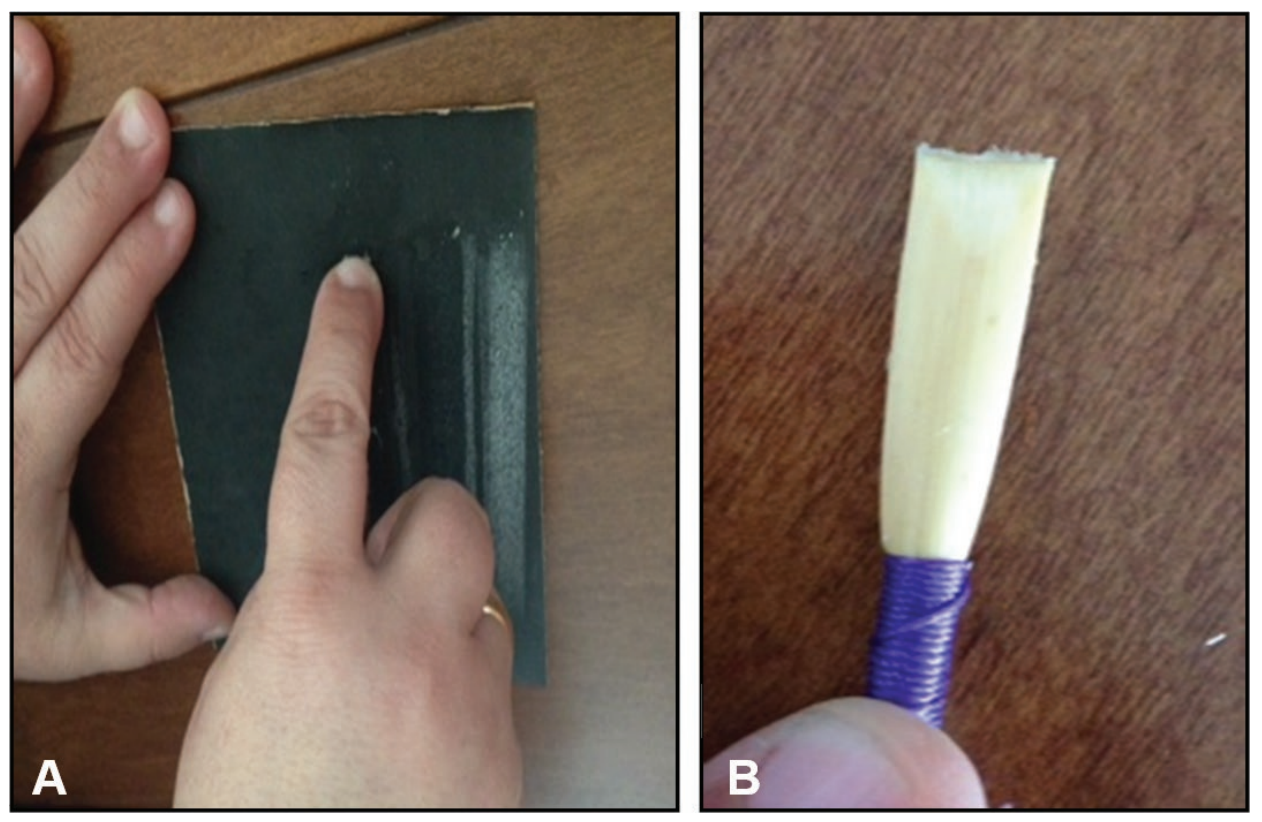

Figura 45: (A) Raspando a ponta com a lixa; (B) Ponta já raspada (Fonte: acervo da autora).

Em seguida, colocar a lingueta entre as duas lâminas e o mandril no tubo para que sirva de apoio para a raspagem. Medir 60,5 mm do final do tubo, sentido ponta, e desenhar a "meia lua" com o lápis. Fazer o mesmo contorno com a faca, delimitando onde a cana será raspada (Figura 46). 


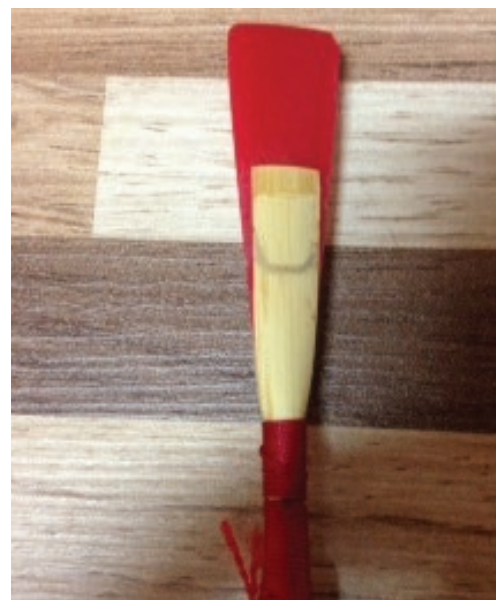

Figura 46: Marcação do início da raspagem (Fonte: acervo da autora).

Retirar o verniz da cana a partir de onde foi marcado com o lápis até a direção da ponta. É importante que se mantenha a coluna de verniz no meio da cana, pois esta será responsável pelo equilibrio e vibração da mesma (Figura 47).
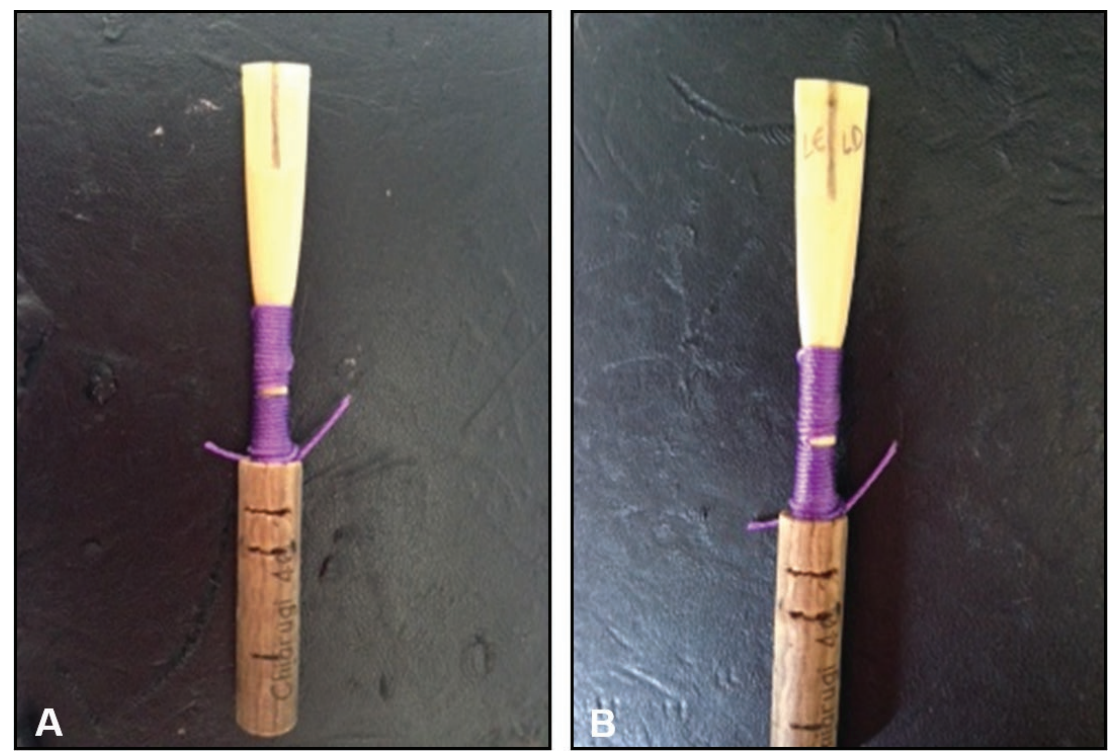

Figura 47: (A) Marcação da coluna; (B) Marcação do lado direito (LD) e do lado esquerdo (LE) (Fonte: acervo da autora). 
Tem-se a marcação feita a lápis da coluna no centro da cana, e os lados direito e esquerdo, denominados de LD e LE. Medir 2,5 mm de distância da lateral da cana até a ponta fazendo a marcação de um " $\bigvee$ " ao contrário com a faca, delimitando onde será raspada (Figura 48).

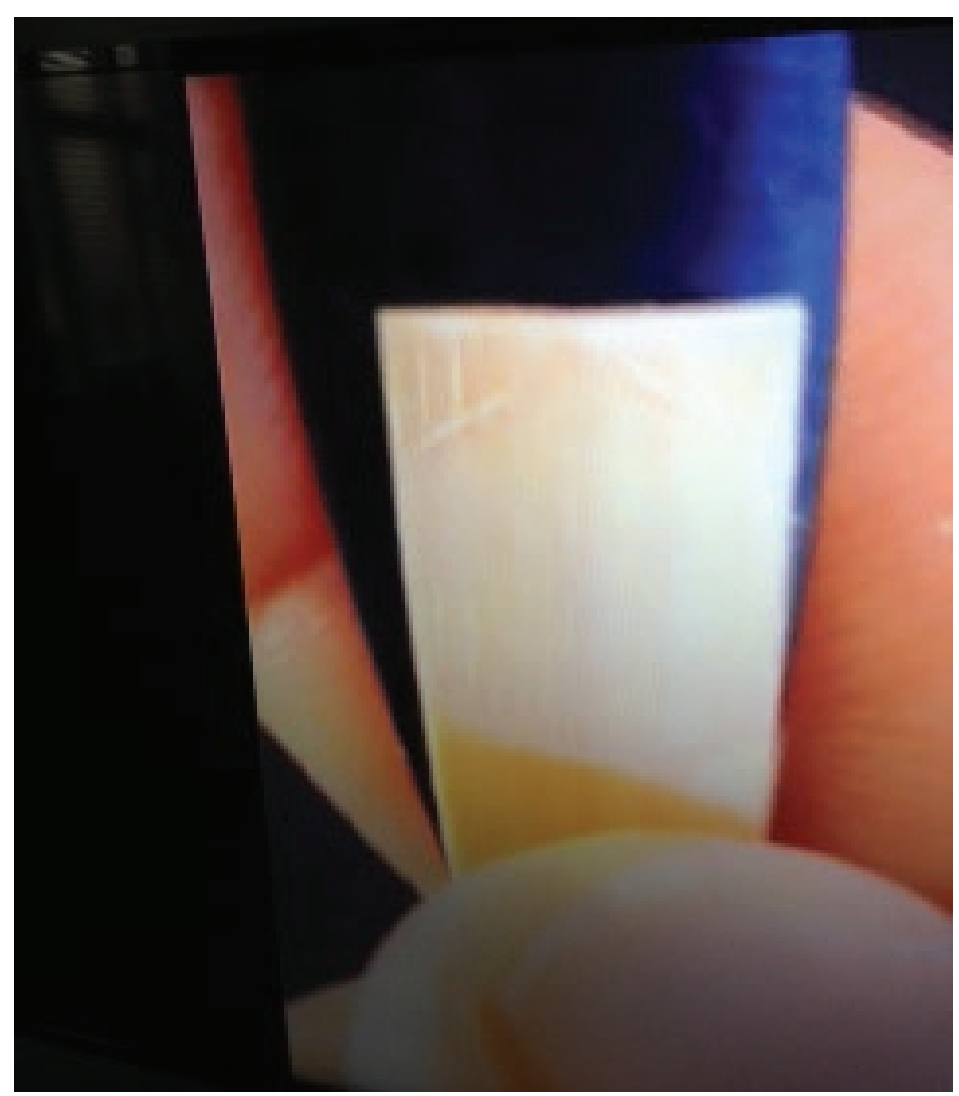

Figura 48: Marcação da raspagem da ponta (Fonte: acervo da autora). 
Em seguida, raspar as laterais da ponta na região onde foi delimitado na marcação anterior (Figura 49).
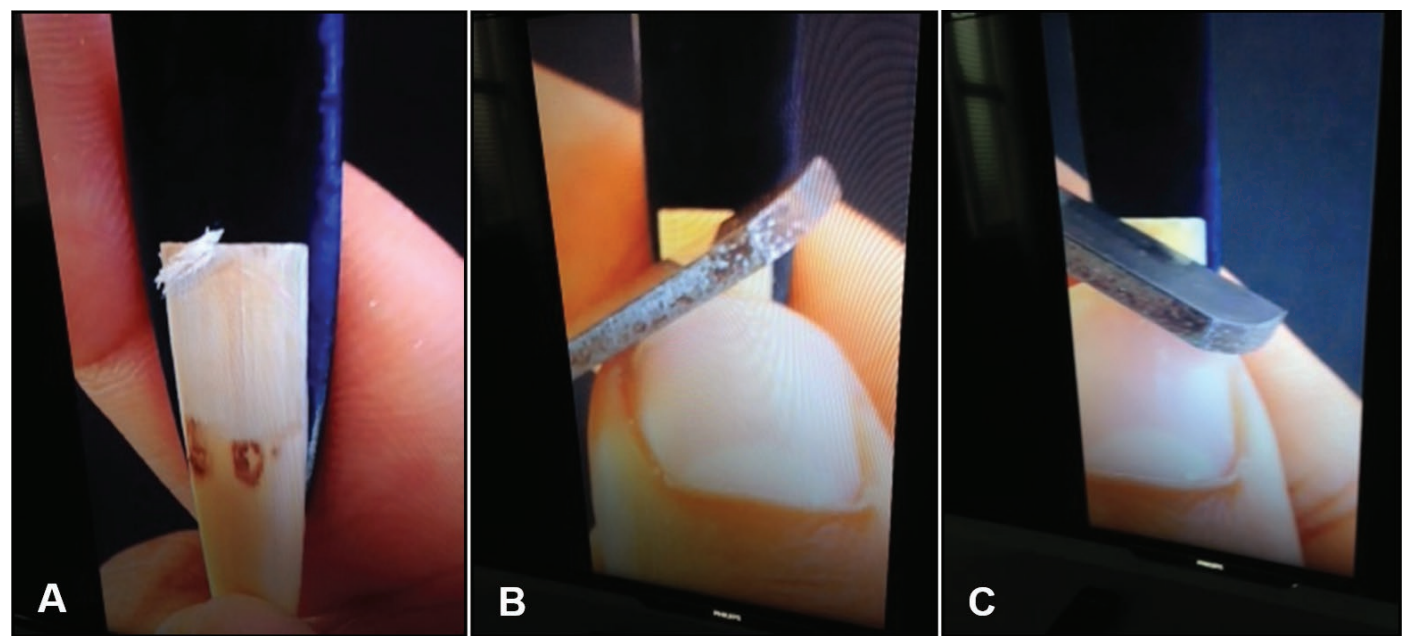

Figura 49: Raspando a ponta da palheta (Fonte: acervo da autora).

Raspar sempre do centro da cana para as laterais, até atingir a espessura de 8 a 6 mm. Usar o micrômetro para obter precisão nas medidas (Figura 50). 


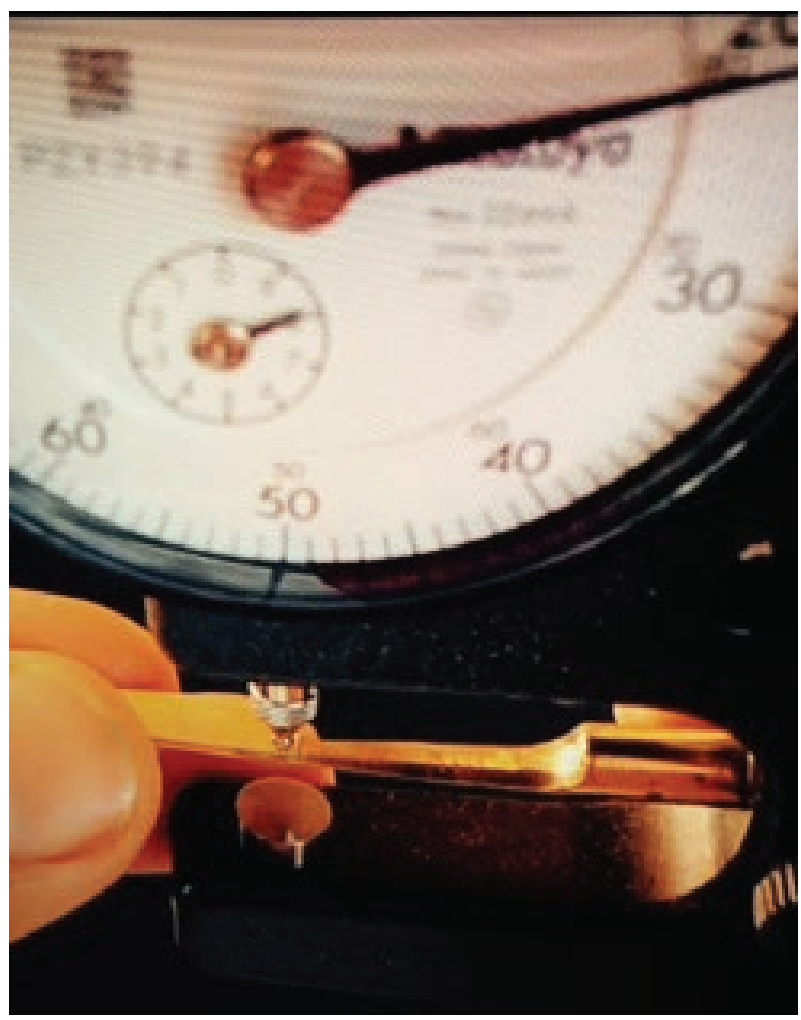

Figura 50: Medindo a ponta da palheta com micrômetro (Fonte: acervo da autora).

Manter a mesma quantidade de raspados nos dois lados para que se obtenha a simetria, isto é, se raspar cinco vezes do lado direito da cana, fazer o mesmo do lado esquerdo, assim como na lâmina oposta. Tomar muito cuidado ao raspar a ponta da cana. Essa é a região menos espessa de toda a palheta. Qualquer deslize comprometerá todo o trabalho já realizado, porém é comum que aconteçam deslizes no início da aprendizagem. 
Observe na Figura 51 que, após ter chegado nesse estágio da raspagem, fica um "degrau" entre a ponta e o coração, que deve ser atenuado com sutileza para que haja equilibrio da sonoridade aguda, média e grave.

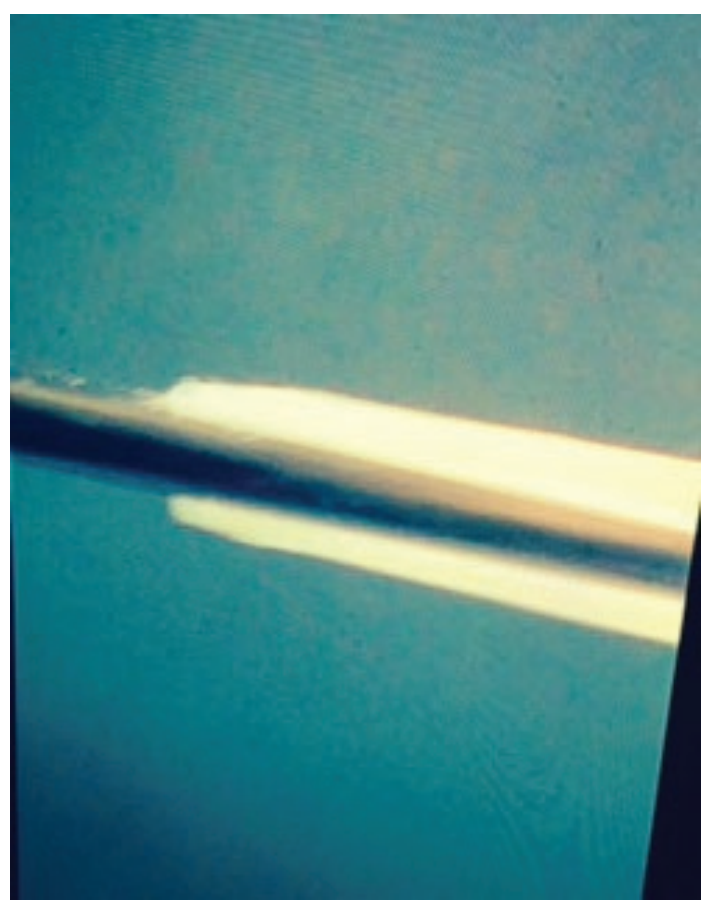

Figura 51: "Degrau" na ponta da palheta.

A próxima etapa da raspagem será retirar o excesso de cana das laterais direita e esquerda, no sentido da ponta. Raspar-se-á da "meia-lua", já delimitado após a raspagem da ponta, retirando a cana gradativamente, ou seja, a base do raspado será sempre mais espessa que a ponta (Figura 52). 


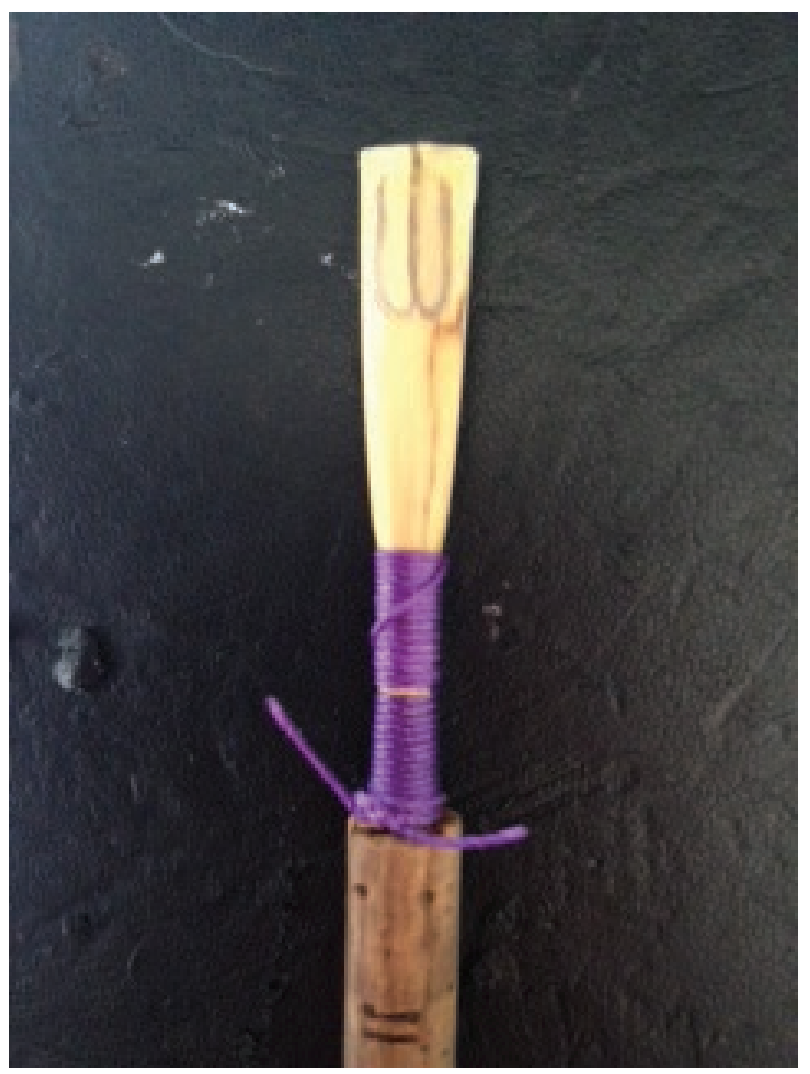

Figura 52: Marcação do "W” (Fonte: acervo da autora).

A Figura 52 indica a região da cana em que se deve raspar nos lados direito e esquerdo. Manter um "W" quando se raspa essa região da palheta, preservando a coluna central e as laterais.

A medida da raspagem da base do raspado deve ser de 50 mm. Depois, devem-se seguir as medidas de 48, 30, $25 \mathrm{~mm}$ até a ponta com 8 a $6 \mathrm{~mm}$. As medidas sugeridas irão depender da espessura e densidade da cana. Recomenda-se que a cana tenha de 56 a $60 \mathrm{~mm}$ de espessura e 9 a 12\% de densidade. Caso obtenha essas medidas e a palheta ainda não soe como o esperado, deve-se raspar um pouco mais, sempre mantendo a coesão da base possuir mais material do 
que a ponta. Deve-se sempre tomar cuidado durante a raspagem em manter a coluna do início da "meia lua" até a ponta, para que se tenha estabilidade na vibração da palheta. Neste estágio, a palheta já está quase pronta. Recomenda-se que durante o processo da raspagem, o oboísta sopre as lâminas para verificar a flexibilidade das mesmas, evitando que se retire em demasia o material da cana ou que se deixe material em excesso. Também é importante soprar a palheta junto ao instrumento durante o procedimento da raspagem para sentir como soa no mesmo.

Outro fator importante é o clima do local onde a cana será raspada: calor, frio, muita ou pouca umidade, e ambientes com ar condicionado, pois fazem com que a cana reaja de maneiras diferentes. Cabe ao oboísta adequar-se às características do local onde usará a palheta. Também é importante que a raspagem seja realizada com muita cautela. Pode demorar alguns dias para que a palheta corresponda a todas as atribuições esperadas de equilibrio timbrístico, flexibilidade e afinação.

\section{Considerações Gerais}

Embora a construção de palhetas seja uma prática bastante antiga, datando desde o ano 3000 a.C, há carência de produção acadêmica, se comparado a tantos tratados existentes de interpretação, escritos por compositores e executantes como Quantz, Bach, Bozza, Gillet e tantos outros nomes do meio musical.

A explicação para essa carência metodológica talvez se justifique pelo caráter, eminentemente artesanal, da construção de uma palheta. Além disso, é uma atividade que requer grande habilidade manual, sensibilidade dos olhos para detectar detalhes no raspado e de experiência técnica para avaliar características de uma cana como flexibilidade, elasticidade e sonoridade. Tais habilidades são resultados de muitas tentativas, que levam anos para se desenvolver, porém apenas quem se dispõe a conquistá-las consegue ter êxito. 
Apesar de existirem algumas publicações sobre esse assunto, a eficácia da aprendizagem se dá mediante observação visual e experiência prática, atos que não podem ser substituidos por material impresso. Inegavelmente, livros, métodos e vídeos contribuem para a organização e o desenvolvimento prático e proporcionam conhecimentos teóricos que complementam e explicam a conduta detalhada no manuseio da cana e dos equipamentos que o oboísta enfrenta diariamente. Os recursos teóricos não substituem o "fazer" sua própria palheta, o "perder" muitos materiais enquanto se aprende, o "cortar" o dedo no manuseio da faca afiada. Mas esse desafio se torna imensamente gratificante quando se toca o oboé com a palheta que se conseguiu fazer: soar, articular e afinar.

\section{Referências}

BURCES G, Haynes B. The oboe - Yale musical instrument series. London: Yale University Press, 2004.

LEDET DA. Oboe reed styles: theory and practice. $2^{\circ}$ Ed. Bloomington, EUA: Indiana University Press, 2008, 224p.

NEUHAUS RK, Schalkwijk B, SOTELO A, Universidad Nacional Autónoma de México Escuela Nacional de Música. Manual de construcción de cañas para oboés. $1^{\circledR}$ Ed. México: UNAM, Escuela Nacional de Música, 1998.

SHALITA J. Making oboe reeds - "A guide to reed making", 2003. Disponivel em: <http://www.makingoboereeds.com>. Acesso em: Março de 2015. 


\section{Sobre as autoras}

Josiane Cristina Cicolani é Bacharel em Música pela Faculdade de Filosofia, Ciências e Letras de Ribeirão Preto - USP, com habilitação em instrumento. Foi aluna de João Carlos Coering, Rodrigo Müller e Joel Gisiger. Participou de Masterclass com os oboístas Alex Klein, Luís Carlos Justi, Roberta Benjamim Barbosa, Gordon Hunt (Inglaterra), David Bertozzi (Itália), Zeliha Budak (Turquia). Participou do Festival Internacional "Fiato al Brasile" (Itália), Festival de Música de Londrina, Festival de Música de Santa Catarina (FEMUSC), Festival de Música de Trancoso - BA e do Festival de Campos do Jordão. Participou de formações artísticas das óperas " $\bigcirc$ Barbeiro de Sevillha", "O Empresário", " A Flauta Mágica”, "O Morcego", "La Traviata", "Carmina Burana" e do musical "West Side Story". Foi bolsista da USP - Filarmônica (RP) de 2011 a 2015, da Mogiana Jazz Band e do Quinteto de Sopros "Pau a Pique". É integrante da Orquestra Sinfônica de Ribeirão Preto desde 2014.

Simone Gorete Machado iniciou ainda criança seus estudos de piano. Logo começou a participar de concursos tendo sucesso em vários desses eventos. Em meados dos anos 90 recebeu bolsas de estudos da Universidade de Hartford onde obteve seu Mestrado e sua Especialização em Piano Performance. Posteriormente mudou-se para - Arizona onde prosseguiu com seus estudos obtendo Doutorado em Piano Performance / Music in General Education na Universidade do Arizona. Retornou ao Brasil 12 anos depois, ingressando como docente, na Universidade de São Paulo, no câmpus de Ribeirão Preto. Como convidada do TEDxPhoenix representou a Biosphere2 onde desenvolveu trabalhos que buscam unir música e ciências. Atualmente, tem se dedicado a pesquisas e projetos na área de música tais como oficinas, grupos de pesquisa, publicação de livros e organização de eventos, oferecendo oportunidades para estudantes desenvolverem seu potencial.

Recebido em 06/08/2017

Aprovado em 27/09/2017 